\title{
HONEYCOMB SPACER CRUSH STRENGTH TEST RESULTS
}

(U)

by

D. R. Leader

Westinghouse Savannah River Company

Savannah River Site

Aiken, South Carolina 29808

A document prepared for:

\section{DISCLAIMER}

\begin{abstract}
This report was prepared as an account of work sponsored by an agency of the United States Government. Neither the United States Government nor any agency thereof, nor any of their employees, makes any warranty, express or implied, or assumes any legal liability or responsibility for the accuracy, completeness, or usefulness of any information, apparatus, product, or process disclosed, or represents that its use would not infringe privately owned rights. Reference herein to any specific commercial product, process, or service by trade name, trademark, manufacturer, or otherwise does not necessarily constitute or imply its endorsement, recommendation, or favoring by the United States Government or any agency thereof. The views and opinions of authors expressed herein do not necessarily state or reflect those of the United States Government or any agency thereof.
\end{abstract}

DOE Contract No. DE-AC09-89SR18035

This paper was prepared in connection with work done under the above contract number with the U.S.

Department of Energy. By acceptarice of this paper, the publisher and/or recipient acknowledges the U.S. Government's right to retain a nonexclusive, royalty-free license in and to any copyright covering this paper, along with the right to reproduce and to authorize others to reproduce all or part of the copyrighted paper. 
WSRC-TR-93-448

\title{
HONEYCOMB SPACER STRENGTH TEST RESULTS (U)
}

\author{
D. R. LEADER
}

SEPTEMBER 15, 1993

Westinghouse Savannah River Company P. O. Box 616

Aiken, S. C. 29802

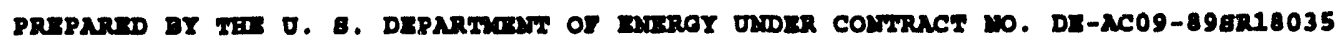




\section{DISCLAIMER}

This report was prepared as an account of work sponsored by an agency of the United States Government. Neither the United States Government nor any agency thereof, nor any of their employees, makes any warranty, express or implied, or assumes any legal liability or responsibility for the accuracy, completeness, or usefulness of any information, apparatus, product, or process disclosed, or represents that its use would not infringe privately owned rights. Reference herein to any specific commercial product, process, or service by trade name, trademark, manufacturer, or otherwise does not necessarily constitute or imply its endorsement, recommendation, or favoring by the United States Government or any agency thereof. The views and opinions of authors expressed herein do not necessarily state or reflect those of the United States Government or any agency thereof.

This report has been reproduced directly from the best available copy.

Available to DOE and DOE contractors from the Office of Scientific and Technical Information, P. O. Box 62, Oak Ridge, TN 37831; prices available from (615) $576-8401$.

Available to the public from the National Technical Information Service, U. S. Department of Commerce, 5285 Port Royal Rd., Springfield, VA 22161 
WSRC-TR-93-448

\section{EMT}

EQUIPMENT AND MATERIAL TECHNOLOGY

\begin{tabular}{|c|c|c|}
\hline KEY WORDS: & Energy & $\begin{array}{r}\text { Shipping Package } \\
\text { Recertification } \\
\text { Absorbent Material } \\
\text { Honeycomb } \\
\text { Crush Strength }\end{array}$ \\
\hline ETENTI & & Permanent \\
\hline
\end{tabular}

HONEYCOMBE SPACER CRUSH STRENGTH TEST RESULTS (U)

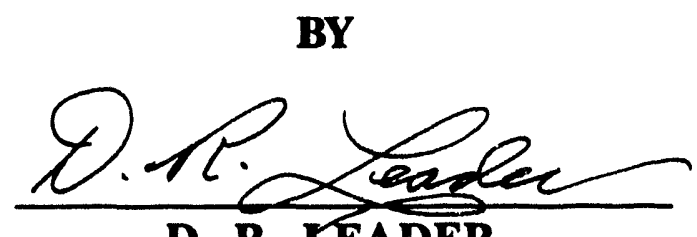

D. R. LEADER

ISSUED: SEPTEMBER 15, 1993

\section{Authorized Derivative Classifier}

D. Themer Ranhi

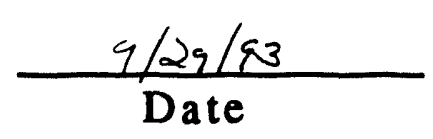

Westinghouse Sovannah Rlver Company Sovennah Plver Silie

Aken, SC 29808

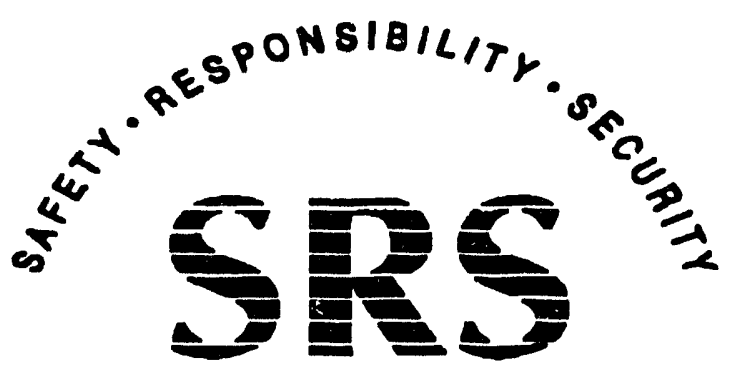

SAVANNAH RIVER SITE 
DOCUMENT: WSRC-TR-93-448

TITLE: HONEYCOMB SPACER CRUSH STRENGTH TEST RESULTS (U)

\section{APPROVALS:}

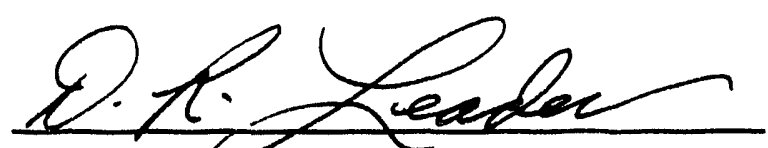

D. R. Leader, Author Materials Technology Section

H. B. Peacock, Technical Reviewer Materials Technology Section
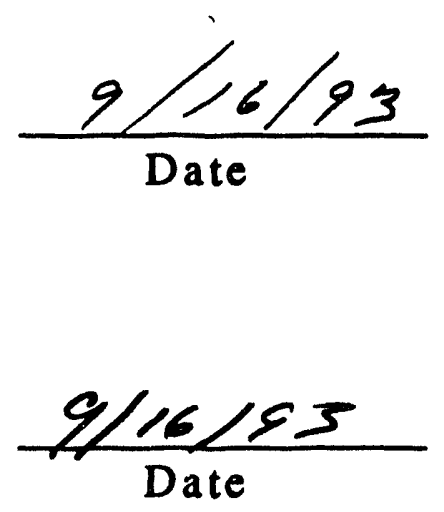

N. C. Iyer, Acting Manager

Materials Application and Corrosion Technology

$\frac{9 / 21 / 93}{\text { Date }}$

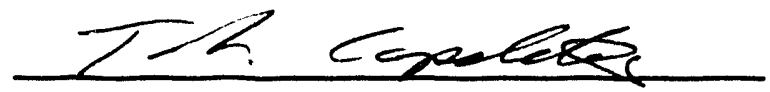

T. L. Capeletti, Manager

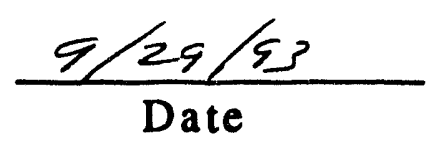


BACKGROUND.

DISCUSSION.

APPENDICES:

APPENDIX 1, S5-2-13100 A, 1000 PSI crush strength 、 6

APPENDIX 2, S5-2-13100 A, 2,000 PSI crush strength 16

APPENDIX 3, S5-2-13100 B, 1,000 PSI crush sterngth 25

APPENDIX 4, S5-2,13100 B, 2,000 PSI crush strength 34

APPENDIX 5, S5-2-13117 C, 1,000 PSI crush strength 41

APPENDIX 6, S5-2-13117 C, 2,000 PSI crush strength 47

APPENDIX 7, Materials Lab Test Machine Data 56

$\begin{array}{ll}\text { DISTRIBUTION: } & 60\end{array}$ 
1. Pre-Crushed Side of Spacer Sample After Crush

2. Undisturbed Side of Spacer Sample After Crush Strength Test

3. Side View Spacer Sample After Crush 


\author{
D. R. LEADER
}

\title{
EXECUTIVE SUMMARY:
}

Aluminum honeycomb spacers, which are used as an energy absorbent material in shipping packages for off site shipment of radioactive materials. were ordered in two crush strengths, 1,000 psi and 2,000 psi for use in drop tests requested by the Packaging and Transportation group as part of the shipping container rectification process. Both the vendor and the SRTC Materials Laboratory performed crush strength measurements on test samples made from the material used to fabricate the actual spacers. The measurements of crush strength made in the SRTC Materials Laboratory are within 100 psi of the measurements made by the manufacturer for all samples tested and all test measurements are within $10 \%$ of the specified crush strength, which is acceptable to the P\&T group for the planned tests.

\section{BACKGROUND:}

Sixty special "pre-crushed" aluminum honeycomb energy absorbent spacers were purchased for use in the shipping package rectification tests. There are three different spacer shapes, and ten spacers of each shape were made with two different crush strength specifications; $1,000 \mathrm{psi}$ and 2,000 psi. The Still-Walter Tool and Manufacturing Company was awarded the contract to fabricate the shipping packages to be used in the recertification tests, so Still-Walter actually negotiated the purchase of the honeycomb from the Hexcel Corporation to meet WSRC specifications.

The Hexcel Corporation purchased $221 / 2$ inch wide rolls of aluminum foil to make "tubes" of aluminum honeycomb. Each $221 / 2$ inch long tube was then cut into short pieces to be machined to the specified shape.

Honeycomb behaves like a bundle of interconnected columns which have a very high load bearing capacity, but once the maximum load is exceeded, the compressive load bearing capacity drops off to a much lower value which is then maintained until the honeycomb structure is completely crushed. The high initial load bearing ability is what makes honeycomb attractive for applications like light weight structural members in airplanes, but it is undesirable for the energy absorbing function that is required for the shipping package application. However, the property of bearing a uniform load while being crushed is the 
property that makes aluminum honeycomb attractive as an energy absorbent material for the shipping package application. All of the honeycomb spacers used in this program have been "pre-crushed" to eliminate or minimize the initial high compressive strength of the material. Pre crushing is done by "dimpling" one surface of the spacer with a ball peen hammer so one end of every aluminum column has been loaded past its maximum compressive strength and has started to deform. Although pre crushing dramatically reduces the initial peak load that can be sustained by the honeycomb, the initial maximum load on a pre crushed sample will always exceed the average load until the pre crushed honeycomb surface deforms to the shape of the surface causing it to deform.

When the honeycomb test sample is crushed between two parallel flat plates, all of the deformation takes place on the pre crushed end of the sample. Figure 1 shows the pre crushed surface of a typical test sample after it has been compressed from its initial thickness of 1-inch to about $1 / 2$ inch thick. Figure 2 shows the other end of that same sample. Notice that there is virtually no deformation of the end of the sample that was not pre crushed. Figure 3 is a side view of the same sample. The upper side of the sample in the photograph was originally pre crushed. Notice in this picture that the failure of the honeycomb starts at the pre crushed end progresses toward the other end, but that there is no apparent deformation of the honeycomb below the area where active deformation is in progress.

Because SRS required certification that the honeycomb meets the crush strength specification, Hexcell cut one test specimen from each tube and had it crushed on a testing machine to determine its crush strength. For aluminum honeycomb, crush strength is defined as the average load after the initial peak load (in pounds per square inch) that the honeycomb will support while being crushed. The results of the manufacturers crush strength measurements are included in table I.

Hexcell also supplied a pre crushed test sample from each tube that had enough material left over after the spacers and the required certification sample were cut from the tube. Nine of the fifteen tubes had enough material left over to obtain a test sample that was one inch long.

\section{DISCUSSION :}

The nine test samples from tubes used to manufacture shipping package spacers have been tested on the Baldwin test machine in the SRTC 
Materials Laboratory. Each one inch thick sarnple was first measured to determine its diameter and then placed between parallel surfaces in the test machine and crushed to approximately one half inch thick at a strain rate of $31 / 4$ inches per minute. Discussions with Hexcell verified that this is the same technique they used in their tests to determine crush strength. A chart of machine load versus displacement was recorded for analysis. The test machine charts for both the manufacturers tests and the SRTC tests are included in the appendices of this report. The crush strength, in pounds per square inch, was calculated for both the SRTC samples and the manufacturers samples by dividing the average load after the initial peak load by the calculated sample area based on measurements of the sample. The specified dimensions of the sample were used to calculate the area of the manufacturers sample when no sample material was supplied to SRTC. The SRTC Materials Lab crush strength measurements are within $100 \mathrm{psi}$ of the values determined by the manufacturer in similar tests of samples from the same honeycomb tube, and all test results are within 10\% of the crush strength specifications. The results of all tests are included in table I. The samples from one tube used to manufacture five 2,000 psi spacers per drawing 13100-A had a measured crush trength 22 psi and 76 psi higher than the original specification of 2,000 psi plus orminus 100 psi. The five spacers were accepted for use in the recertification tests based on the knowledge of their actual crush strength and the small deviation from the original specification. Nonconformance Report 92-NCR-11-0159 was written to record the acceptance of these five spacers.

There were six different types of honeycomb spacers purchased from Hexcel. The first six appendices to this report contain all of material data and test results for each type of spacer. Appendix 7 contains a copy of the certificate of calibration for the Materials Lab testing machine and a copy of the chart relating the SRTC machine load to chart pen vertical position. This chart is required for interpreting the SRTC test charts because the machine load is not shown on the Y axis of the SRTC charts.

\section{CONCLUSION:}

The crush strength measurements done in the materials Laboratory confirm the results of tests done by the honeycomb manufacturer. All of the materials lab results are within 100 psi of the manufacturers test results on samples from the same tubes, and all test results are within $10 \%$ of the desired crush strength, which is acceptable for the recertificatin tests planned by the packaging and Transportation group. 
D. R. Leader

September, 1993
WSRC-TR-93-448

Page 4

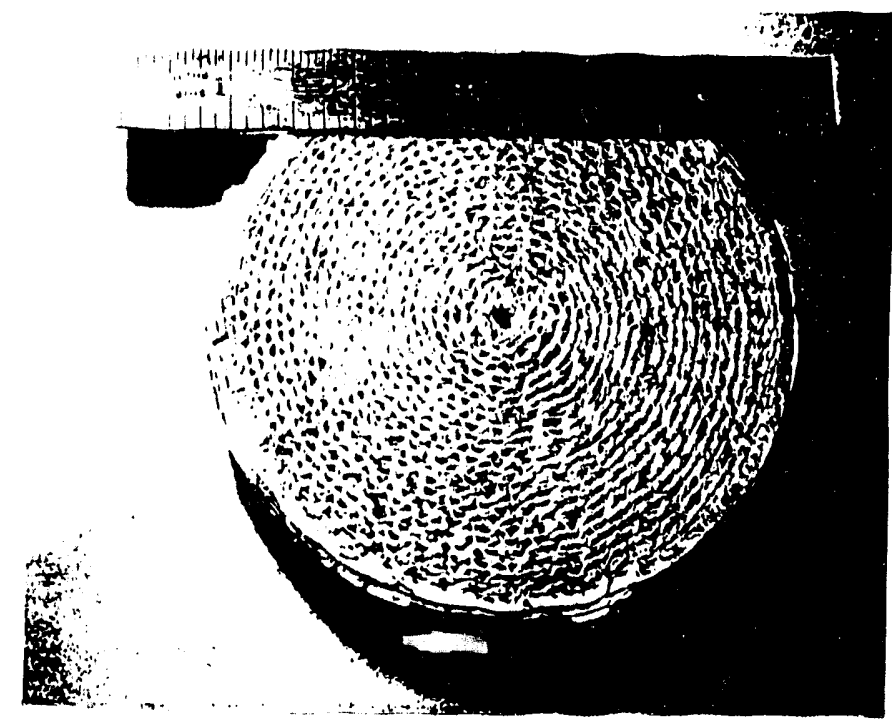

Figure 1

Pre-Crushed Side of Spacer Sample

After Crush Strength Test

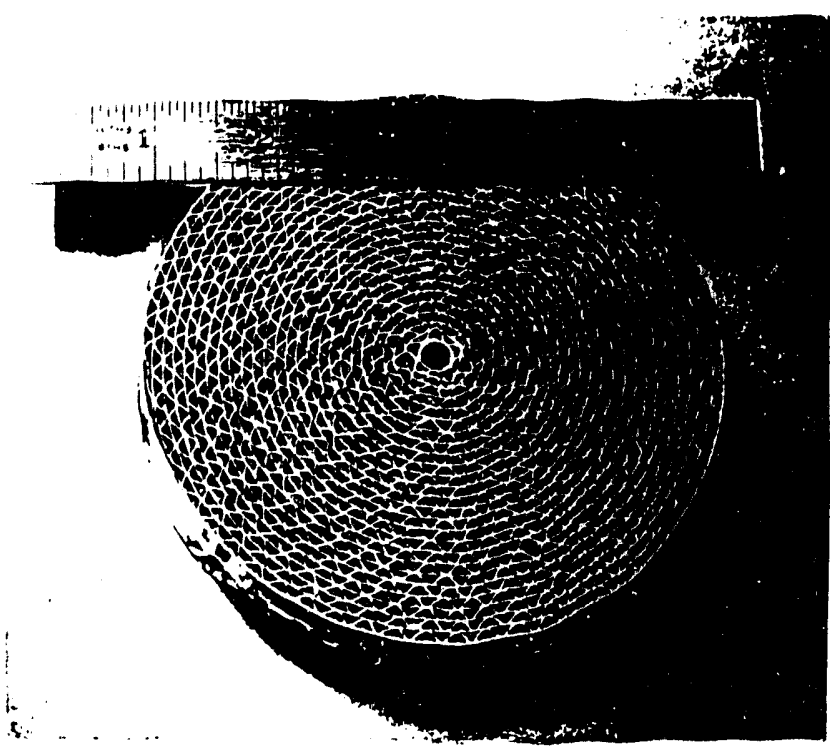

Figure 2

Undisturbed Side of Spacer Sample After Crush Strength Test

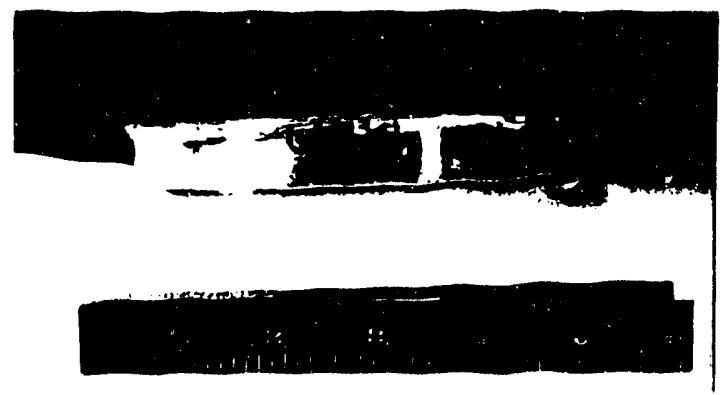

Figure 3

Side View of Spacer Sample After Crush strength Test 
D. R. Leader

September, 1993
WSRC-TR-93-448

Page 5

\section{TABLE I}

\begin{tabular}{|c|c|c|c|c|c|}
\hline $\begin{array}{l}\text { SRS } \\
\text { DRAWING } \\
\text { NUMBER }\end{array}$ & $\begin{array}{l}\text { HEXCELL } \\
\text { TUBE } \\
\text { NUMBER }\end{array}$ & $\begin{array}{l}\text { PIECES } \\
\text { MADE } \\
\text { FROM } \\
\text { TUBE }\end{array}$ & $\begin{array}{l}\text { NOMINAL } \\
\text { CRUSH } \\
\text { STRENGTH }\end{array}$ & $\begin{array}{c}\text { MFG. } \\
\text { MEASURED } \\
\text { CRUSH } \\
\text { STRENGTH }\end{array}$ & $\begin{array}{l}\text { SRTC } \\
\text { MEASURED } \\
\text { CRUSH } \\
\text { STRENGTH }\end{array}$ \\
\hline $\begin{array}{l}13100-A \\
13100-A \\
13100-A\end{array}$ & $\begin{array}{l}93-1 \\
93-2 \\
93-3\end{array}$ & $\begin{array}{l}4 \\
5 \\
1\end{array}$ & $\begin{array}{l}1,000 \\
1,000 \\
1,000\end{array}$ & $\begin{array}{l}1,061 \\
1,014 \\
1,022\end{array}$ & $\begin{array}{r}989 \\
1,033 \\
1,006\end{array}$ \\
\hline $\begin{array}{l}13100-A \\
13100-A\end{array}$ & $\begin{array}{l}93-1 \\
93-2\end{array}$ & $\begin{array}{l}5 \\
5\end{array}$ & $\begin{array}{l}2,000 \\
2,000\end{array}$ & $\begin{array}{l}2,093 \\
2,176\end{array}$ & $\begin{array}{l}2,050 \\
2,122\end{array}$ \\
\hline $\begin{array}{l}13100-B \\
13100-B \\
13100-B\end{array}$ & $\begin{array}{l}93-1 \\
93-2 \\
93-3\end{array}$ & $\begin{array}{l}4 \\
3 \\
3\end{array}$ & $\begin{array}{l}1,000 \\
1,000 \\
1,000\end{array}$ & $\begin{array}{l}953 \\
920 \\
910\end{array}$ & $\begin{array}{c}1,020 \\
997 \\
2\end{array}$ \\
\hline $\begin{array}{l}13100-B \\
13100-B \\
13100-B\end{array}$ & $\begin{array}{l}93-1 \\
93-2 \\
93-3\end{array}$ & $\begin{array}{l}4 \\
4 \\
2\end{array}$ & $\begin{array}{l}2,000 \\
2,000 \\
2,000\end{array}$ & $\begin{array}{l}2,039 \\
2,070 \\
2,039\end{array}$ & $\begin{array}{l}2 \\
2 \\
2\end{array}$ \\
\hline $\begin{array}{l}13117-C \\
13117-C\end{array}$ & $\begin{array}{l}93-1 \\
93-2\end{array}$ & $\begin{array}{l}6 \\
4\end{array}$ & $\begin{array}{l}1,000 \\
1,000\end{array}$ & $\begin{array}{l}1,062 \\
1,012\end{array}$ & 2 \\
\hline $\begin{array}{l}13117-C \\
13117-C\end{array}$ & $\begin{array}{l}93-1 \\
93-2\end{array}$ & $\begin{array}{l}6 \\
4\end{array}$ & $\begin{array}{l}2,000 \\
2,000\end{array}$ & $\begin{array}{l}2,029 \\
1,980\end{array}$ & $\begin{array}{l}1,939 \\
1,943\end{array}$ \\
\hline
\end{tabular}

1 The two test pieces submitted by Hexcell for these two tubes were identified as " 2 " and "93-3 "Neither of these numbers correspond to the numbers of the tubes used to manufacture the spacers. Discussions with Hexcell did not resolve the problem. They said that the two samples were definitely from the two tubes, and speculated that the sample identified as " 2 " should have been 93-2, but they had no explanation for why the sample from tube 93-1 would be labeled 93-3.

2 No sample was supplied from this tube. 


\section{APPENDIX 1 \\ Bottom Spacer \\ Drawing Number S5-2-13100 A \\ 1,000 PSI Crush Strength}

Index:

Still-Walter Toul \& Manufacturing Co.

Certificate of Conformance

ALCOA aluminum foil certificate of conformance

Hexcel honeycomb spacer certificate of conformance

9

Tube 93-1 crush strength test results (Hexcel)

Tube 93-1 crush strength test results (SRTC)

Tube 93-2 crush strength test results (Hexcel)

Tube 93-2 crush strength test results (SRTC)

Tube 93-3 crush strength test results (Hexcel) 


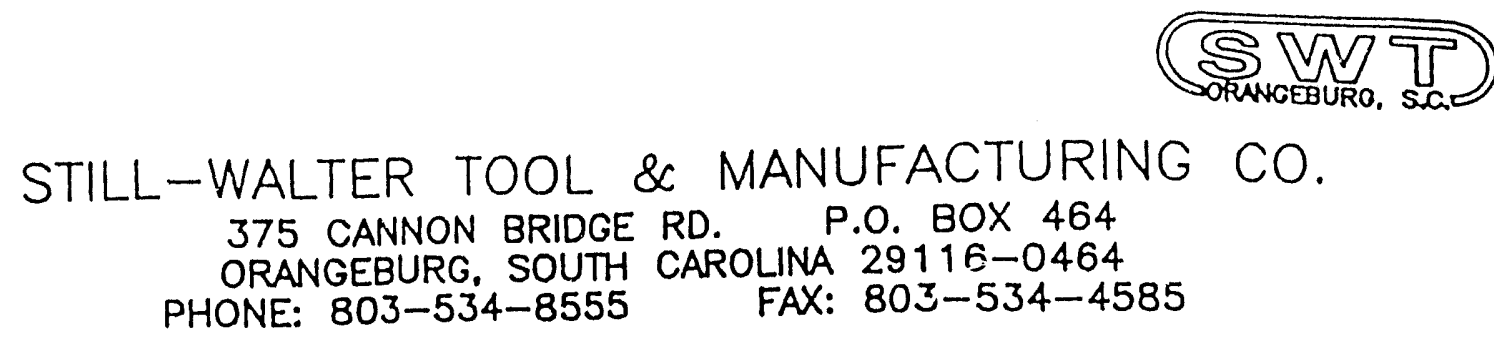

CERTFECATE OF CONFORMANCE

DATE: June 14, 1993

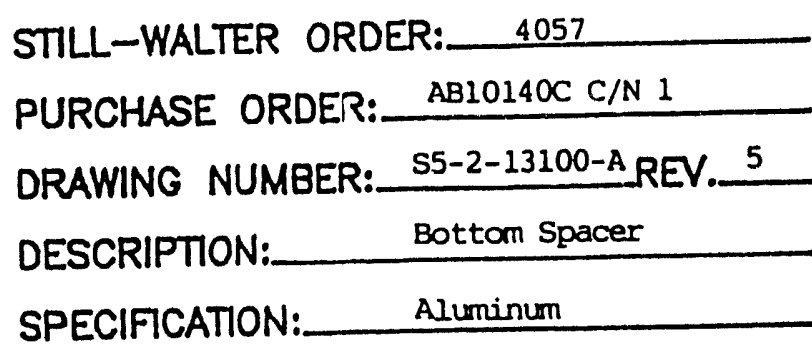

CUSTOMER: Westinghouse SRC

ITEM NUMBER: 6

QUANTITY: 10 EAch

MATERIAL: 5052 Aluminion

Not Applicable

HEAT TREATING: HEAT NUMBER: 168119

PROCUREMENT SPECIFICATION: None

PROCUREMENT LEVEL.

STORAGE LEVEL: Not Applicable

OTHER: 1000 psi Crush Strength Honeycomb

This is to certify that the item fabricated and material used on the above purchose order was manufactured to and conforms with the requirements of applicable drawings and specifications.

Still-Walter Tool \& Manufacturing Co.

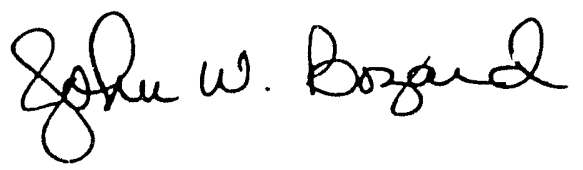

John W. Bozard Quality Assurance Manager 
WSRC Purchase Order No.ABlo140C ClNI

Line Item \# 6

Drawing No. SS-2-1310..A, Rev $\varepsilon$

Description Bttron Spaces (1000 pai)

Page_2 of 6
Q.A. ACCEPTED



A. Aluminum Company Of AMERICA Cust. P.O.
74707

BUFF CERTIFICATION COOO No. MAIOI AkOa No Coritiled
inspoction
Aopor

Product $\rfloor$ PLAIN CUILED HUNEYCUMB FULL WODND ON 3 IN ID FLUSH STEEL CORES I 34 IN OD MAX PER FED SPEC MIL-A

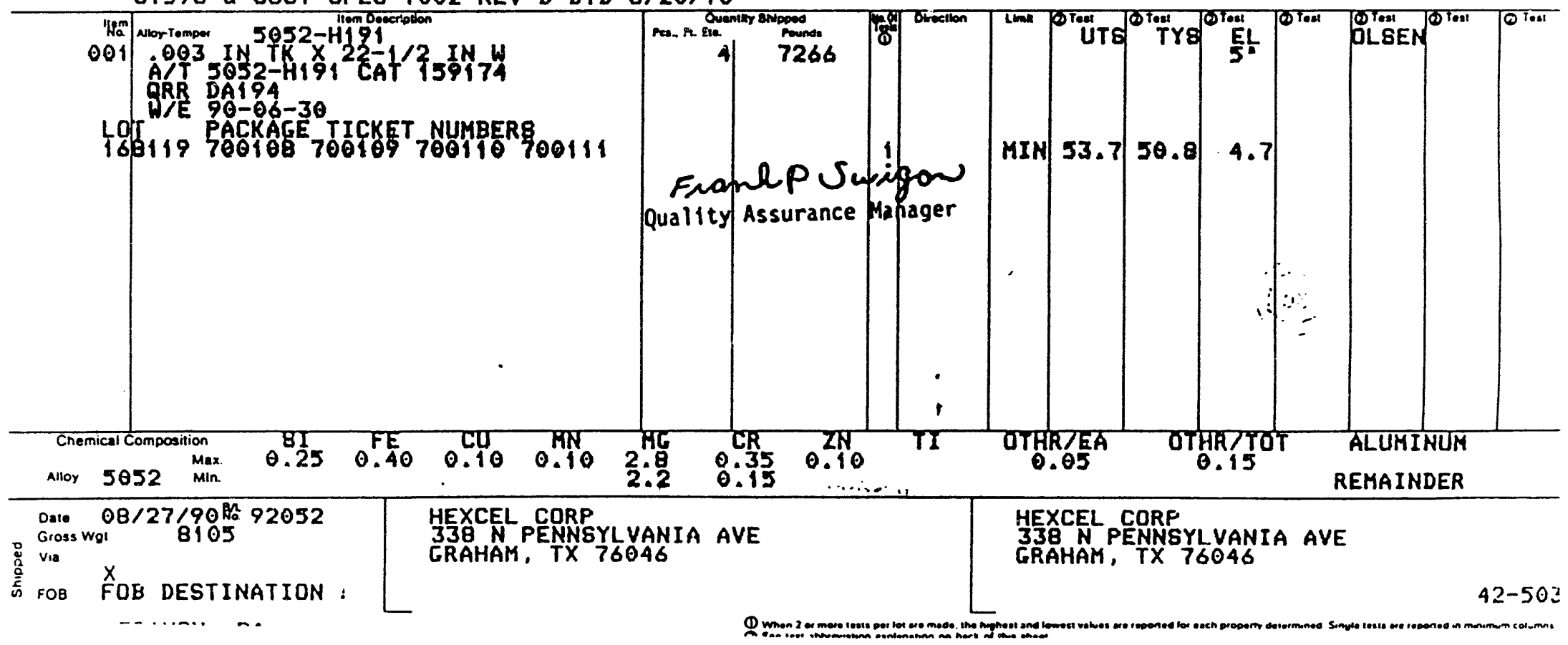




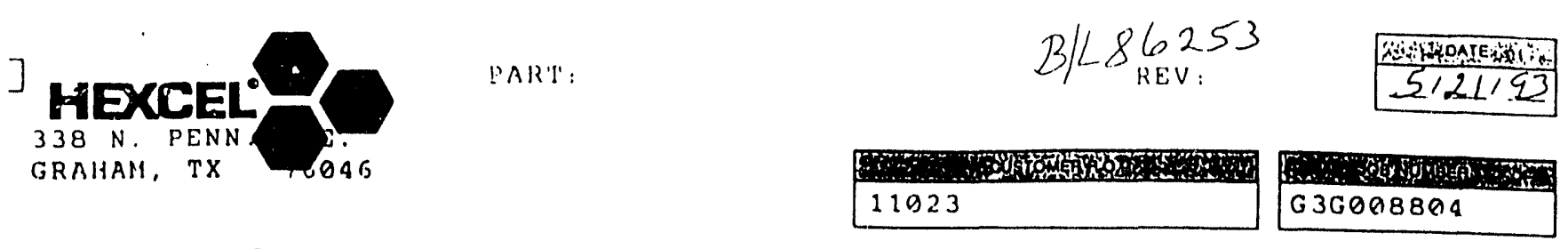

CERTIFICATION:

STILL-WALTER TOOL

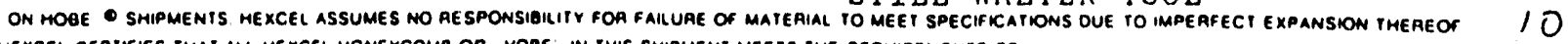

MEXCEL CEATIFIES THAT ALL MEXCEL HONEYCOMB OR HOQE IN IMIS SHIPMENT MEETS IME AEOUIREMENIS OF

$D S \cdot 2 B O Q$

HEXCEL HEREBY CERTIFIES THAT THE PARTS SUPPLIFD

UNDER PO I 1 QZ 3 EULLY CONFORH TO THE DRAWINGS,

SEECIFICATIONS, AND PURCHASE ORDER REOUIREMENT'S.

PART NO.A1526A REV. - SPEC(S) DS- 2800

CRUSH CHARTS IN BOX. SEE ATTACHNENT SHTS FCIR SN'S

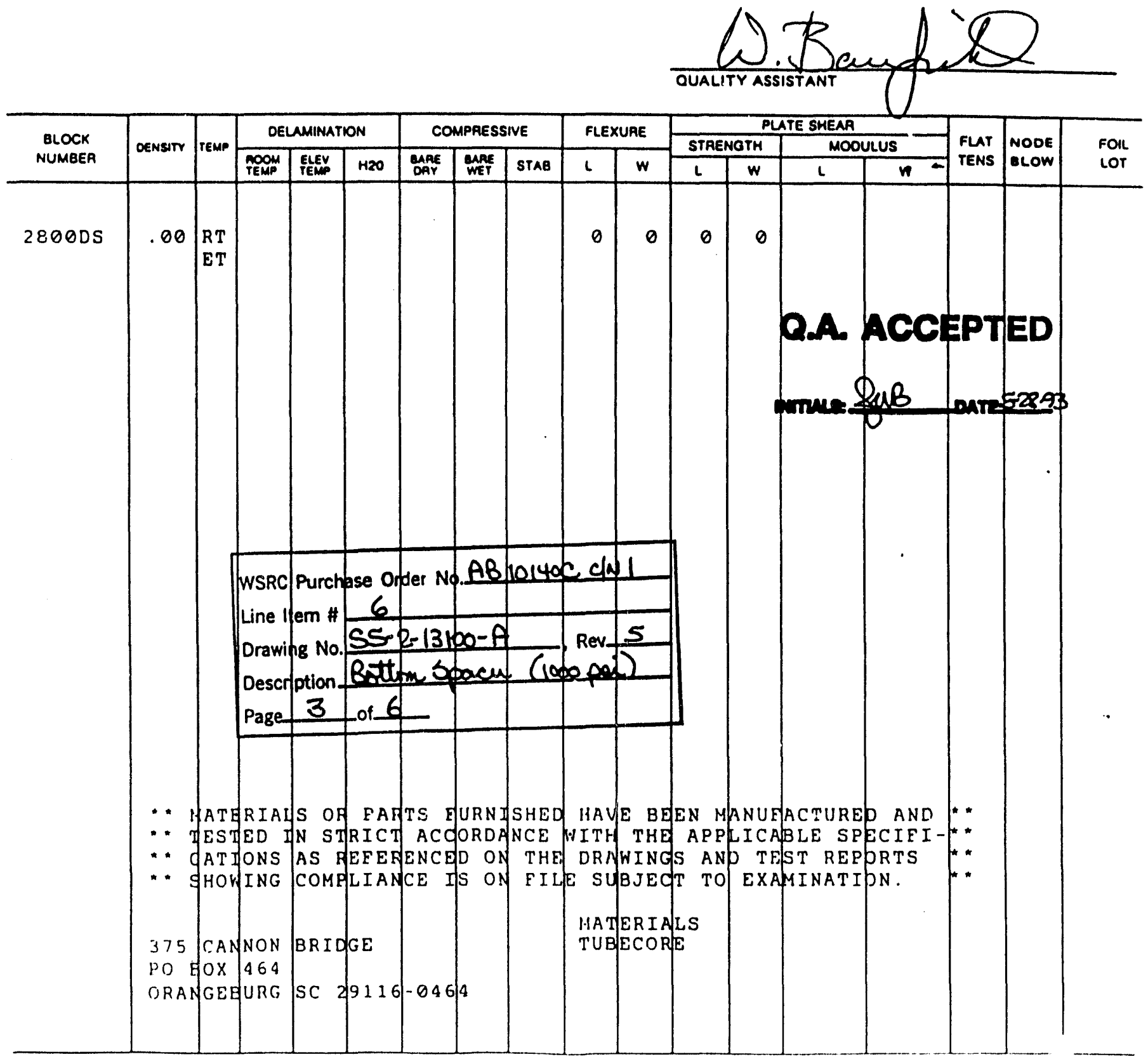




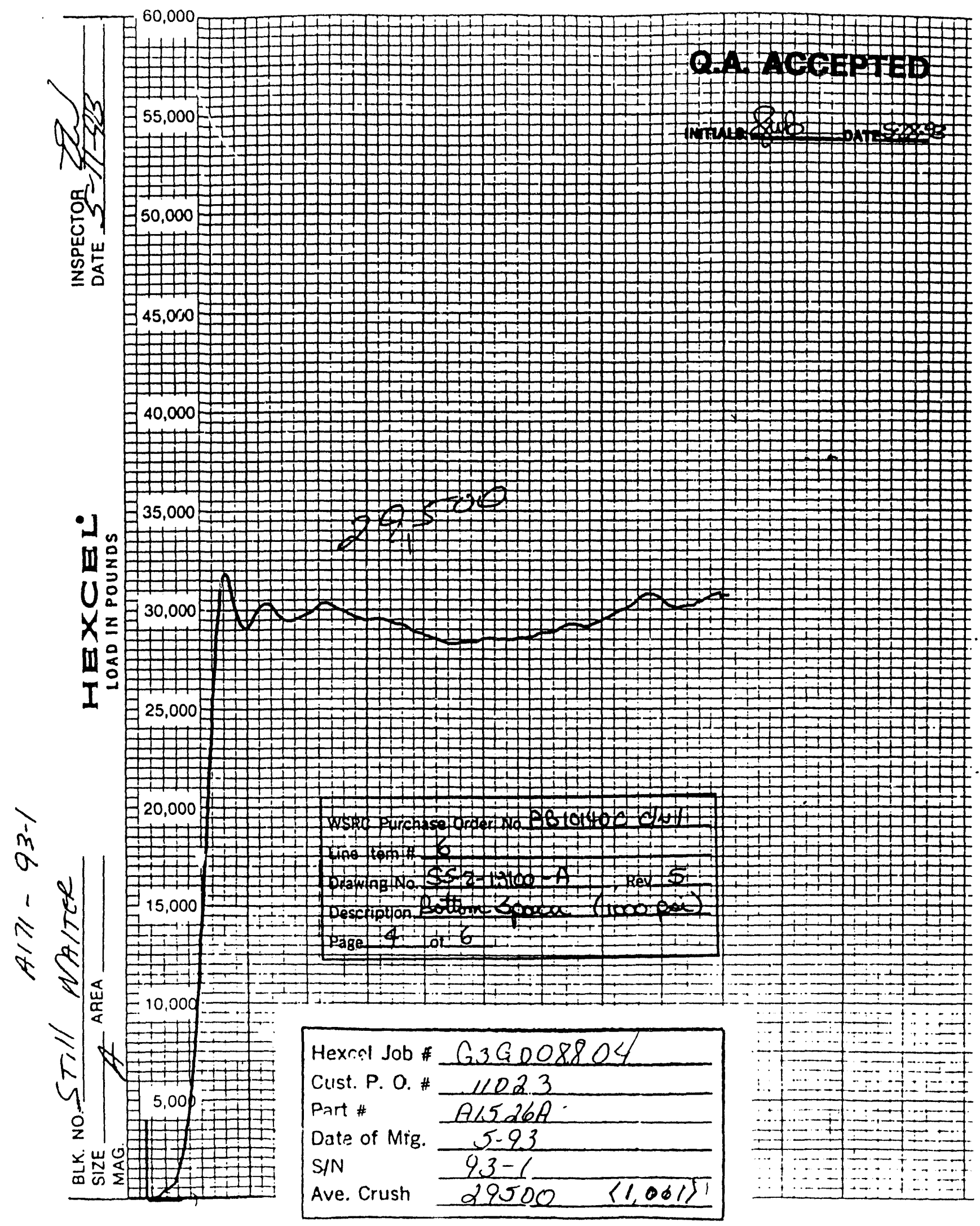


D. R. Leader

September, 1993

WSRC - TR - 93-448

Page 11

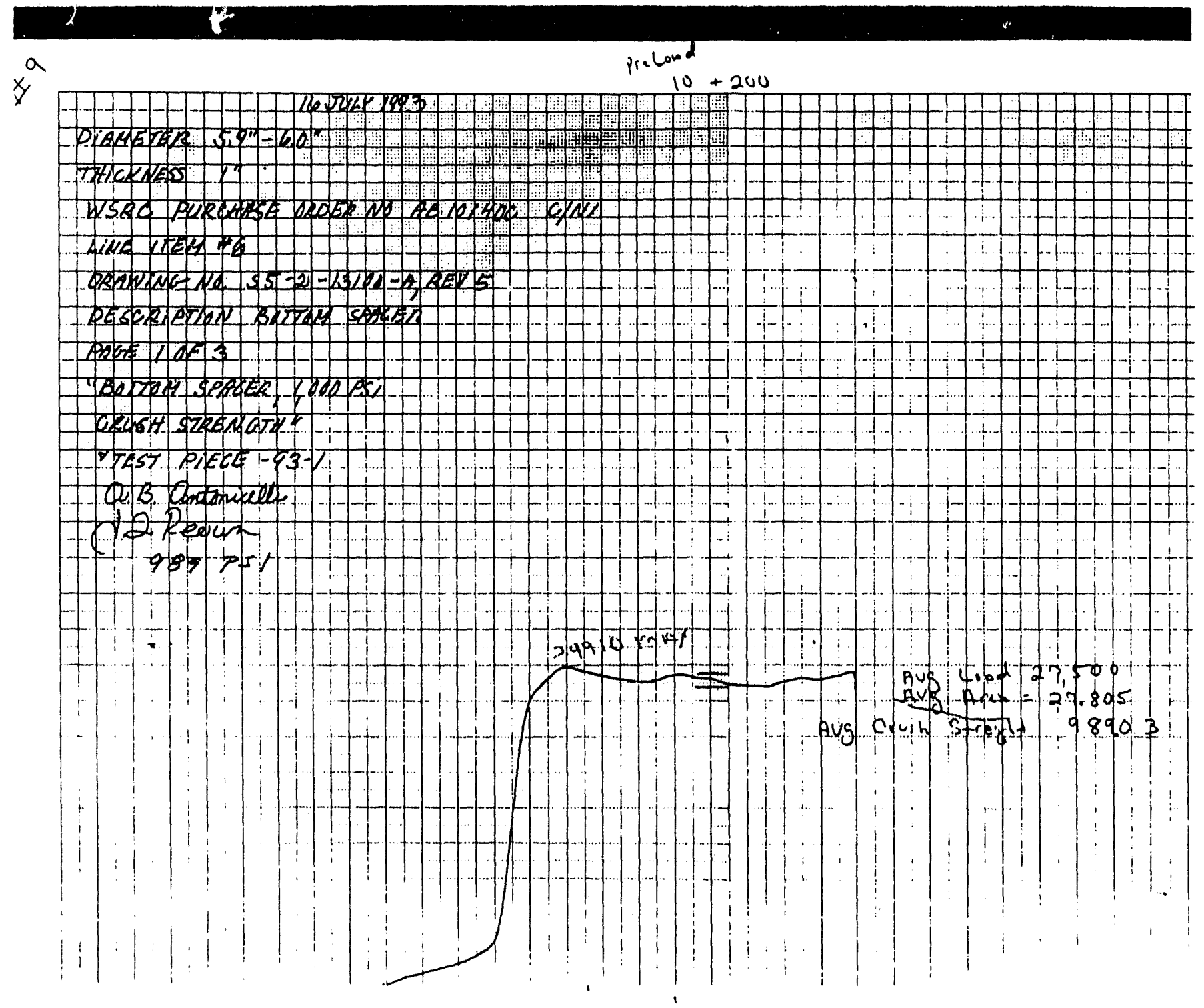


D. R. Leader

September, 1993
WSRC-TR-93-448

Page 12

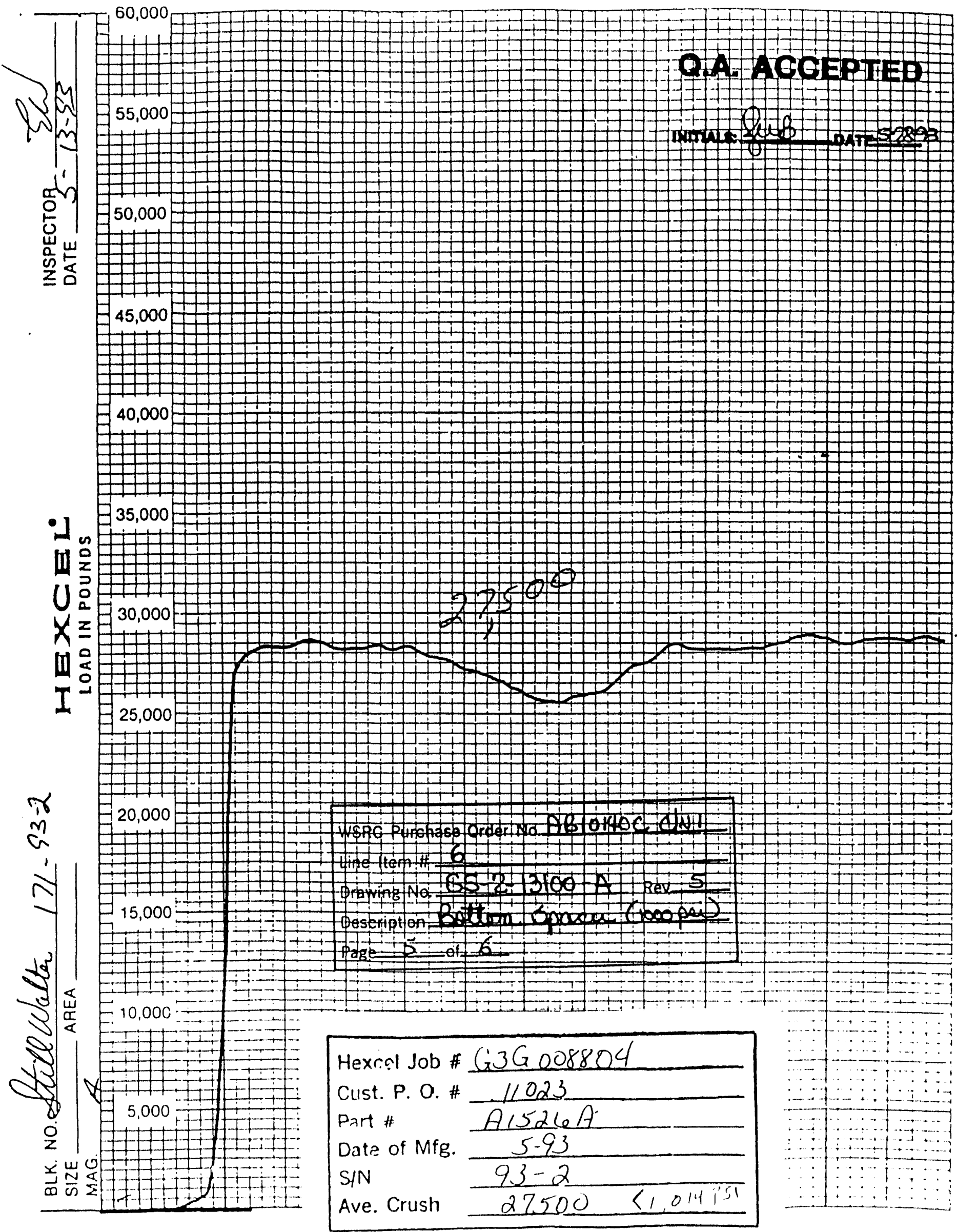


D. R. Leader

September, 1993
WSRC-TR-93-448

Page 13

\section{PRELOAD +190}

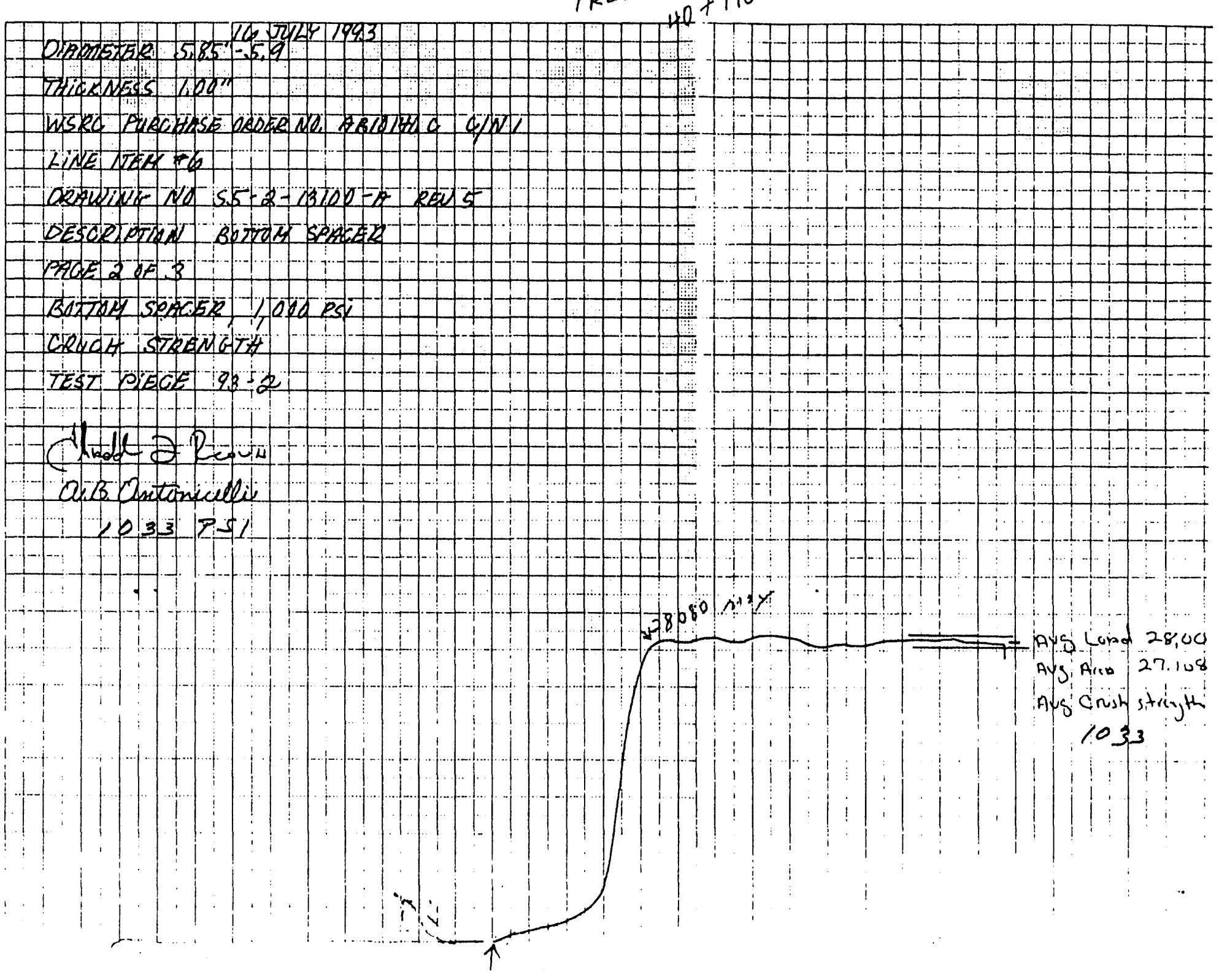




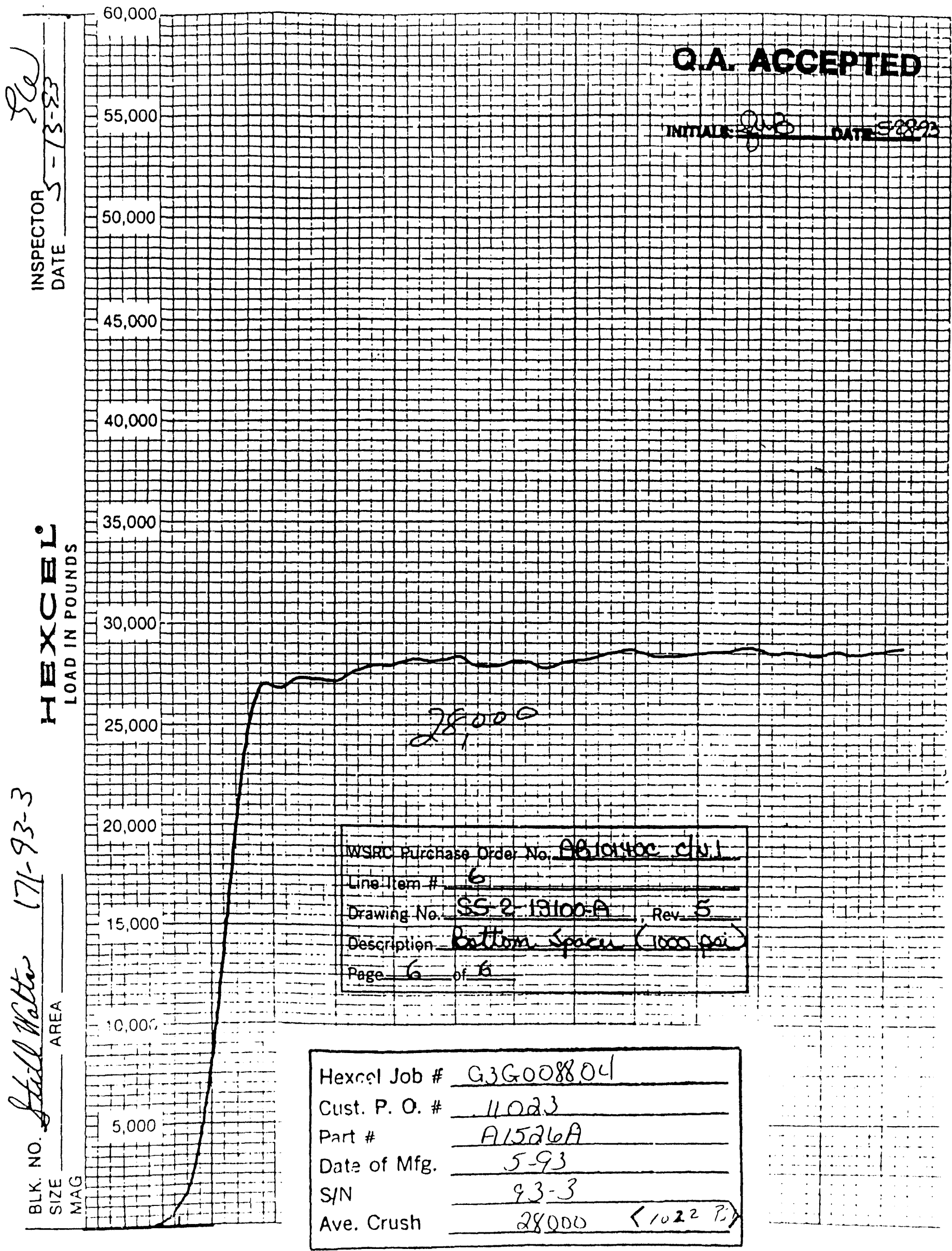


D. R. Leader

September, 1993

WSRC-TR-93-448

Page 15

5

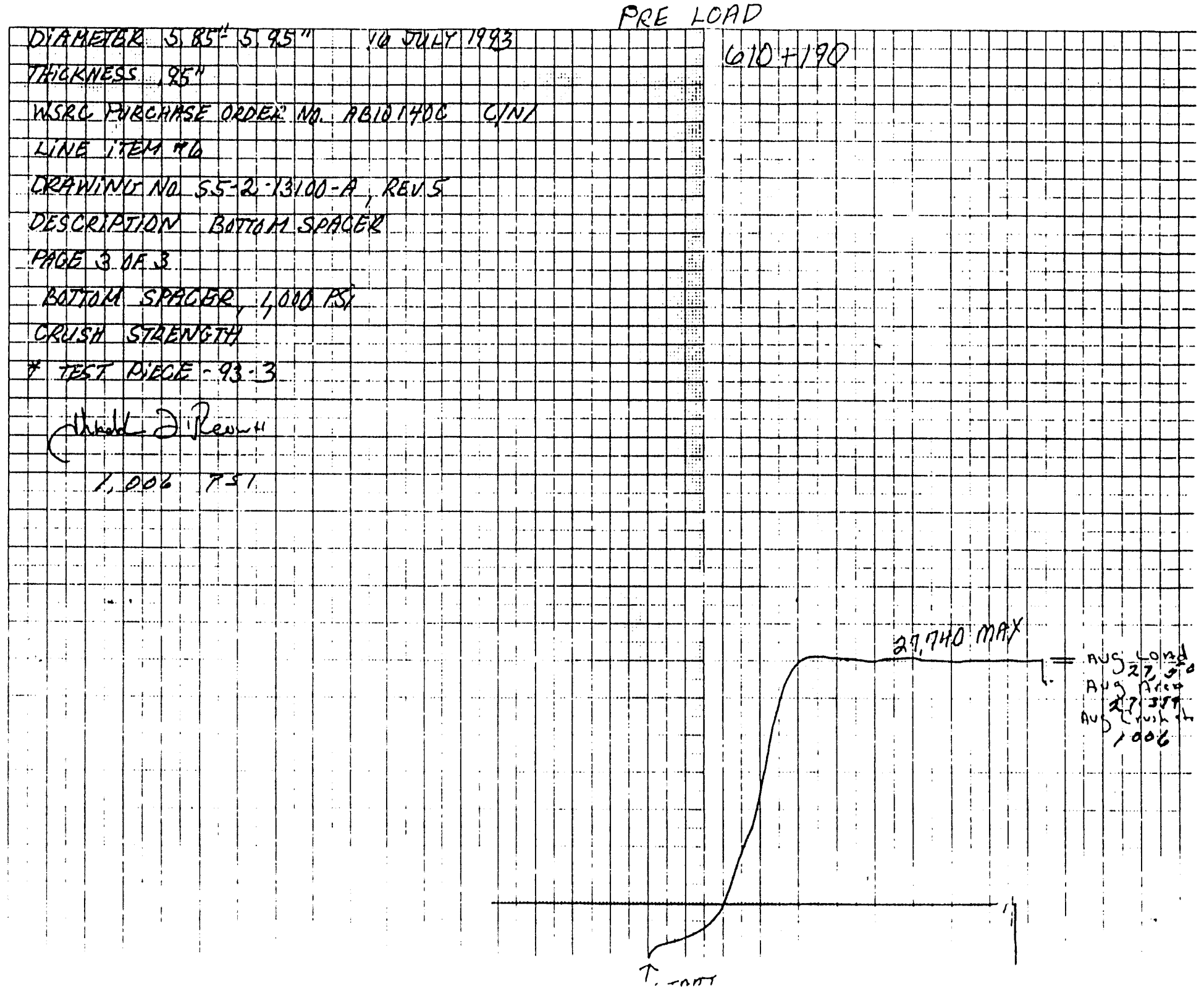




\section{APPENDIX 2 \\ Bottom Spacer \\ Drawing Number S5-2-13100 A \\ 2,000 PSI Crush Strength}

Index:

Still-Water Tool \& manufacturing Co.

Certification of Conformance

$\begin{array}{ll}\text { ALCOA aluminum foil certificate of conformance } & 18\end{array}$

ALCOA aluminum foil certificate of conformance 19

Hexcel honeycomb spacer certificate of conformance 20

Tube 93-1 crush strength test results (Hexcel) 21

Tube 93-2 crush strength test results (Hexel) 22

Tube 93-3 crush strength test results (SRTC) 23

Tube 2 crush strength test results (SRTC) 24 


\section{STILL-WALTER TOOL \& MANUFACTURING CO. 375 CANNON BRIDGE RD. P.O. BOX 464 ORANGEBURG, SOUTH CAROLINA 29116-0464 \\ PHONE: 803-534-8555 FAX: 803-534-4585}

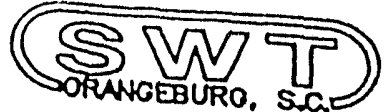

\section{CERTIFICATE OF CONFORMANCE}

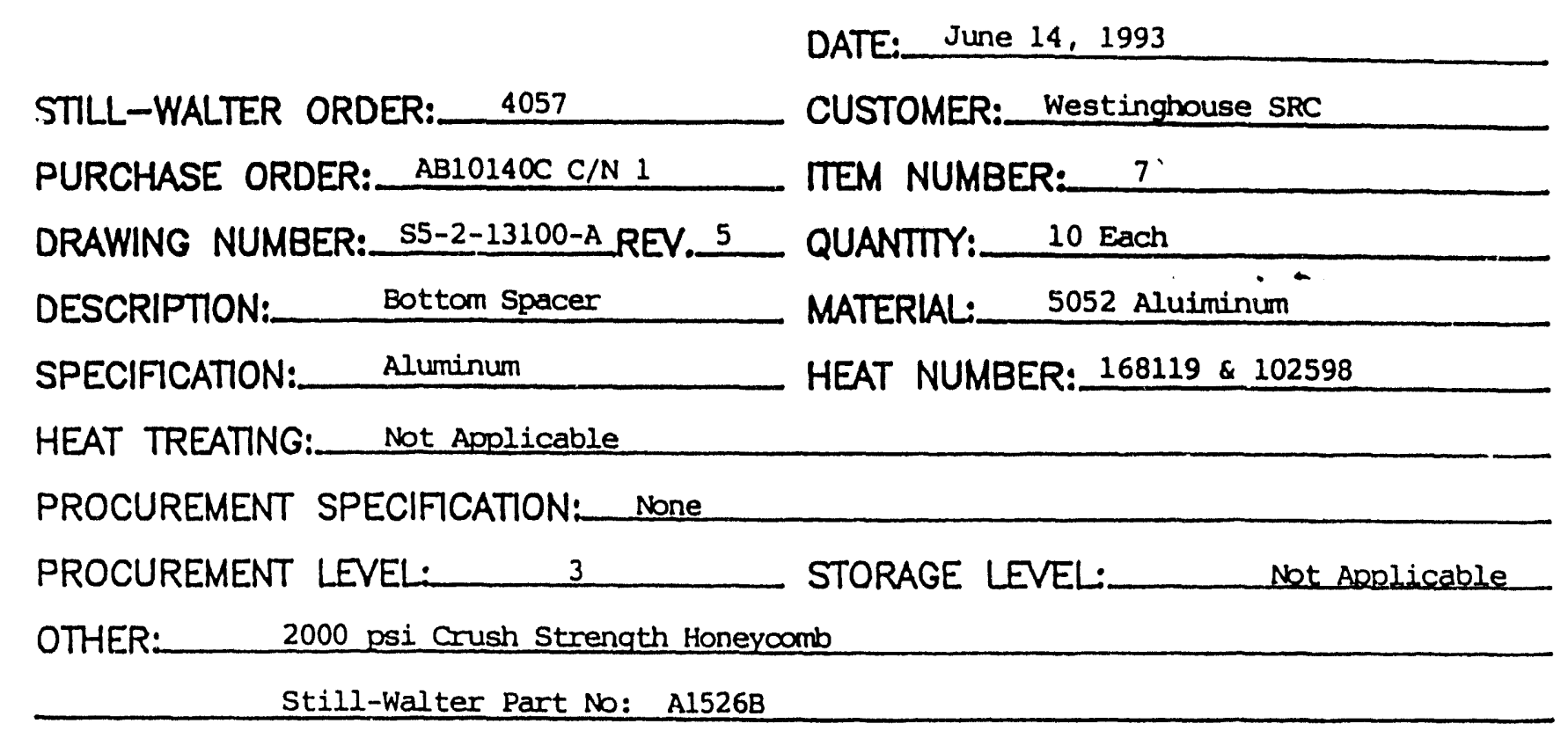

This is to certify that the item fabricated and material used on the above purchase order was manufactured to and conforms with the requirements of applicable drawings and spoclfications. 


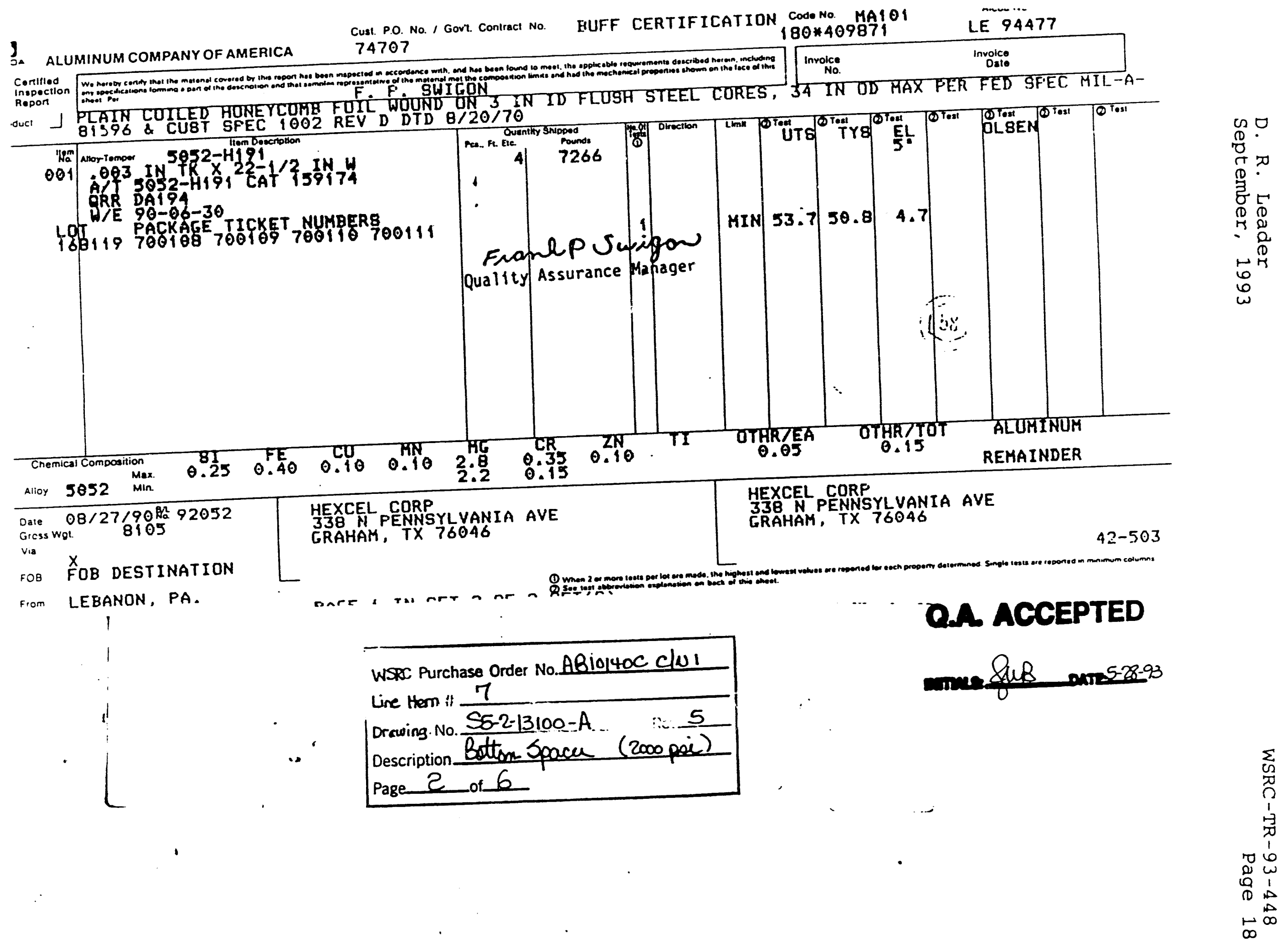




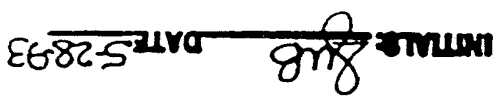

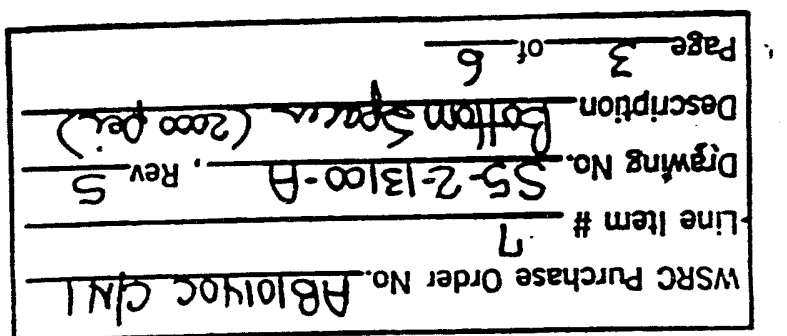

aj1d300V-7ro

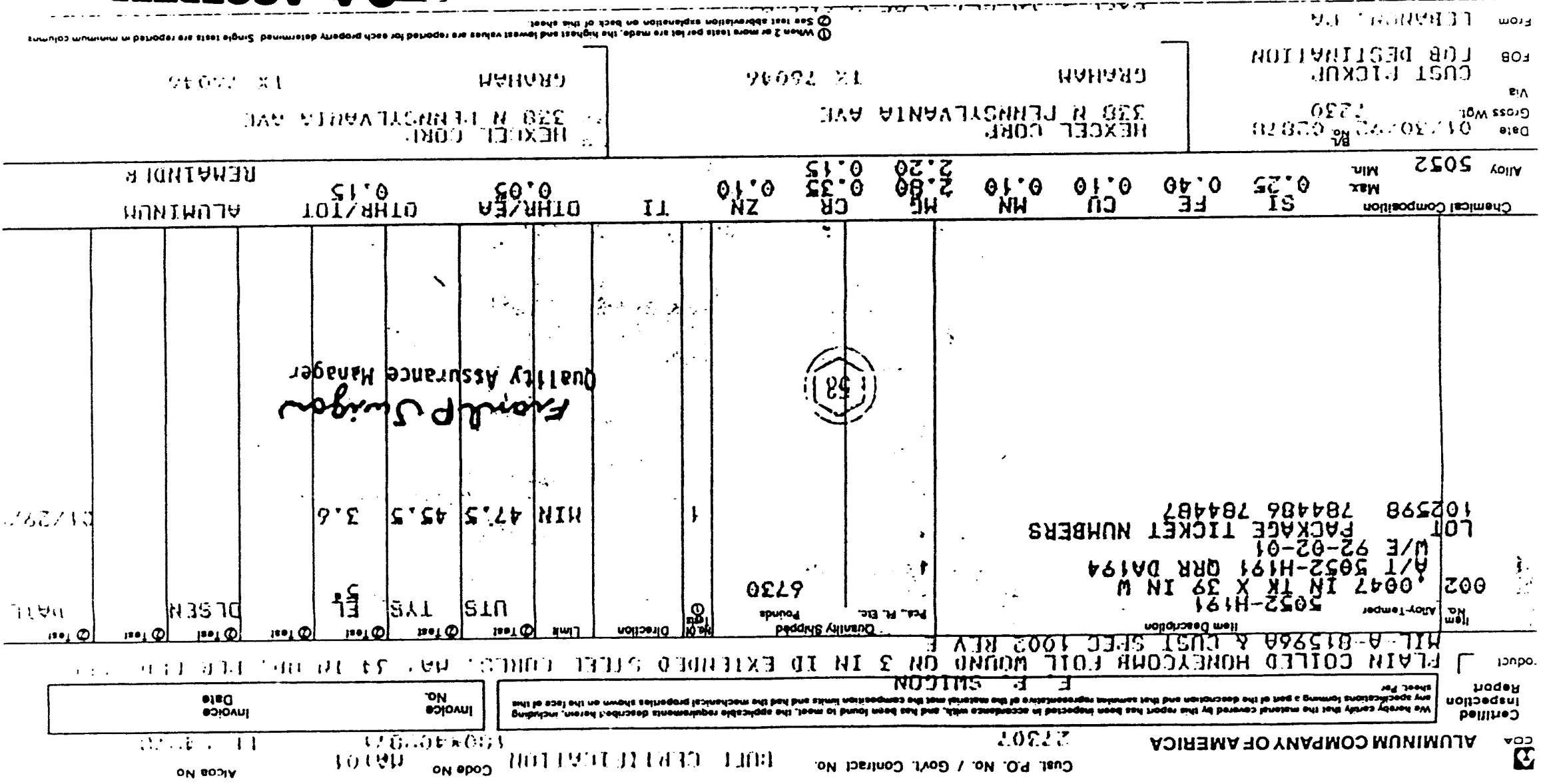


D. R. Leader

WSRC -TR $-93-448$

September, 1993

Page 20

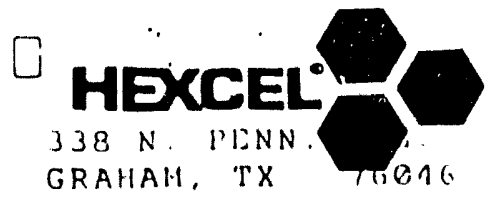

PA.F'T':

$3 / 286253$

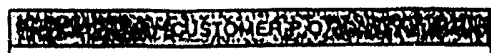

11023

G 3G008805

CERTIFICATION

STILL-HALTER TOOL

on hoge - Shipments mexcel assumes no aesponsigility foa falluag of mateaial to meet specifications due to impeafect expansion theaeor 10

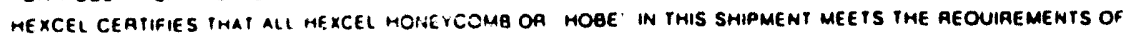

D) $\because \because \because \theta$

HEXCHI, HEYEEY CERTIFIES THAT THE FARTS SUFELIED

UNDEF PO 11023 FULLY CONFORIA TO THE DRAWINGS,

SPECIFICATIONS, AND PURCHASE ORDER REQUIREMENTS.

PART NO. AISZ6B REV. - SPECIS) DS-ZBOO

CRUSH CHARTS IN BOX. SEE ATTACHIENT SHTS EOR SN'S

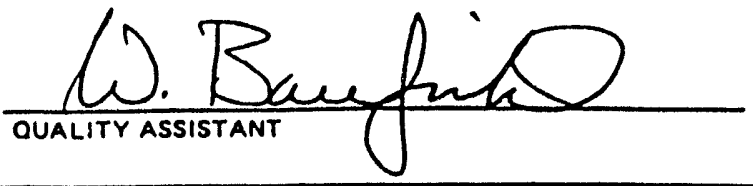

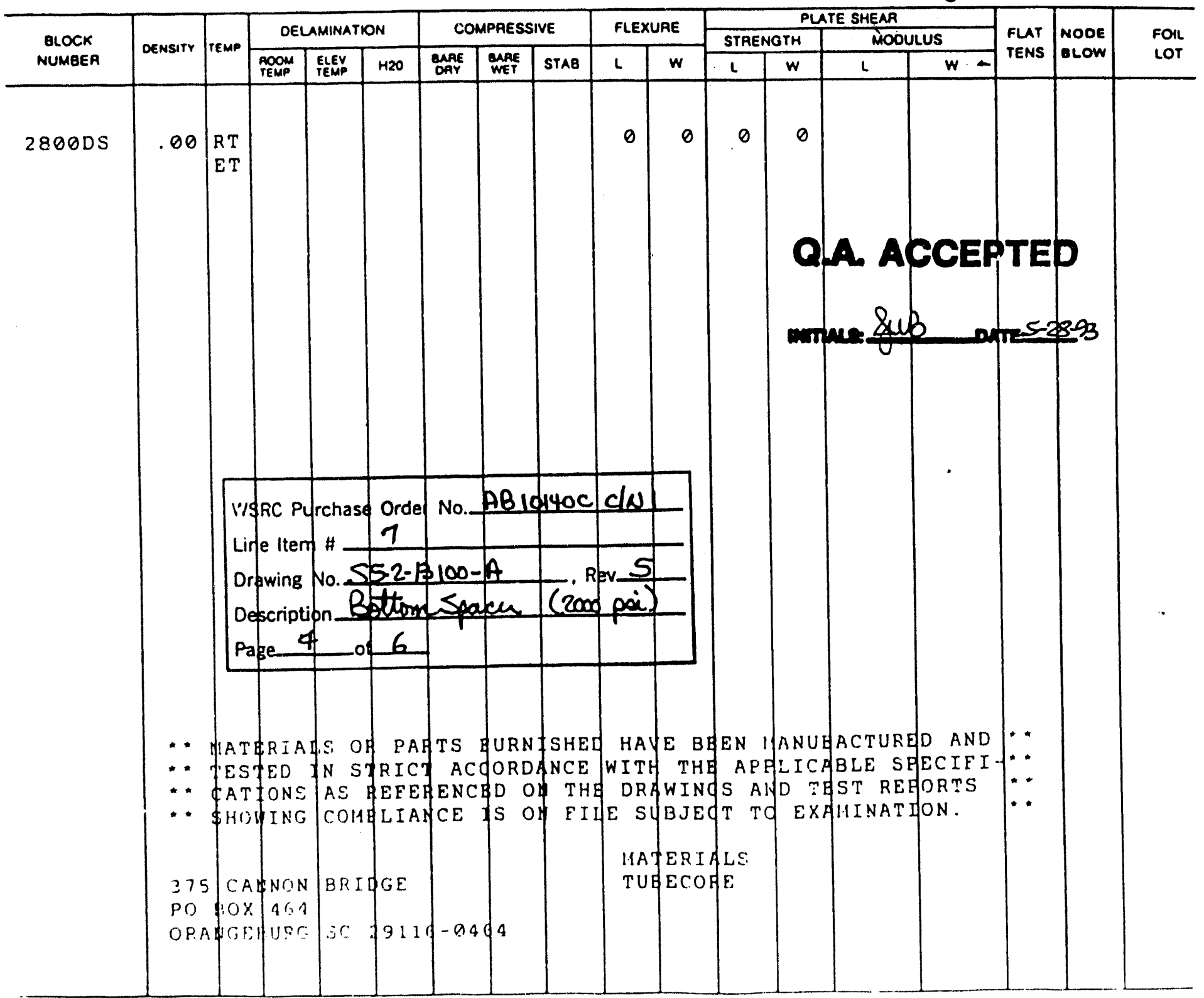


D. R. Leader

September, 1993
WSRC-TR-93-448

Page 21

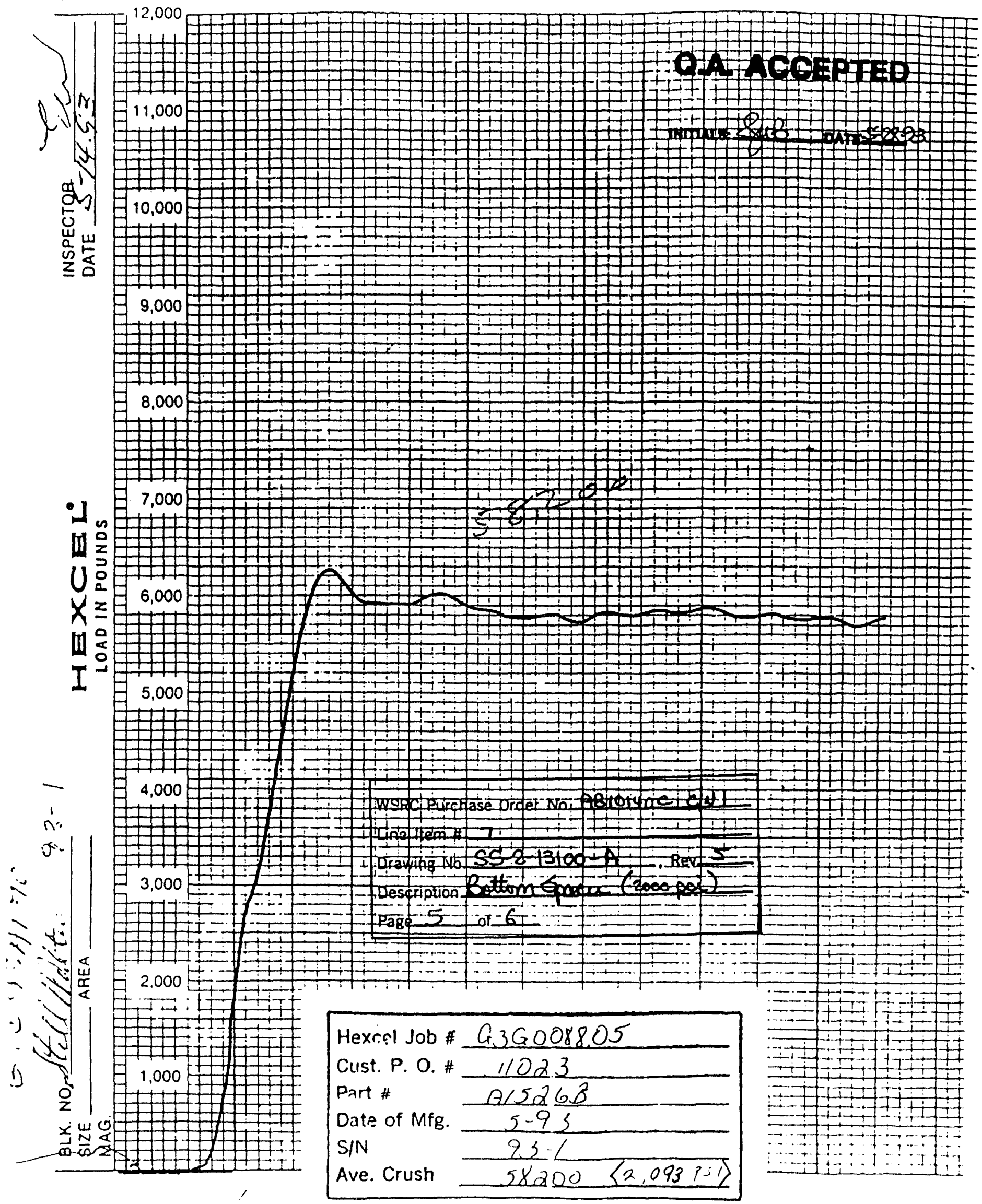




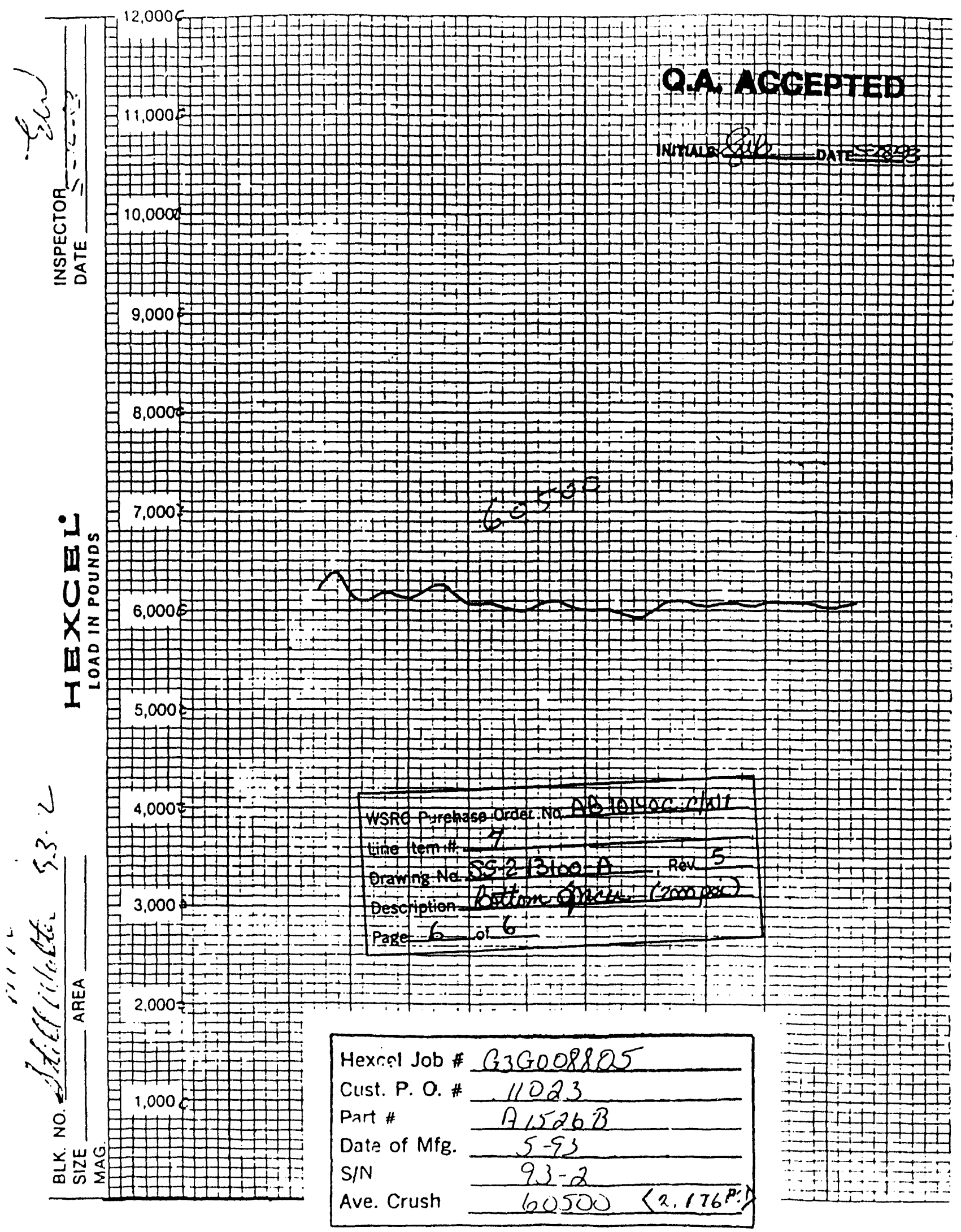


D. R. Leader

September, 1993
WSRC - TR $-93-448$

Page 24
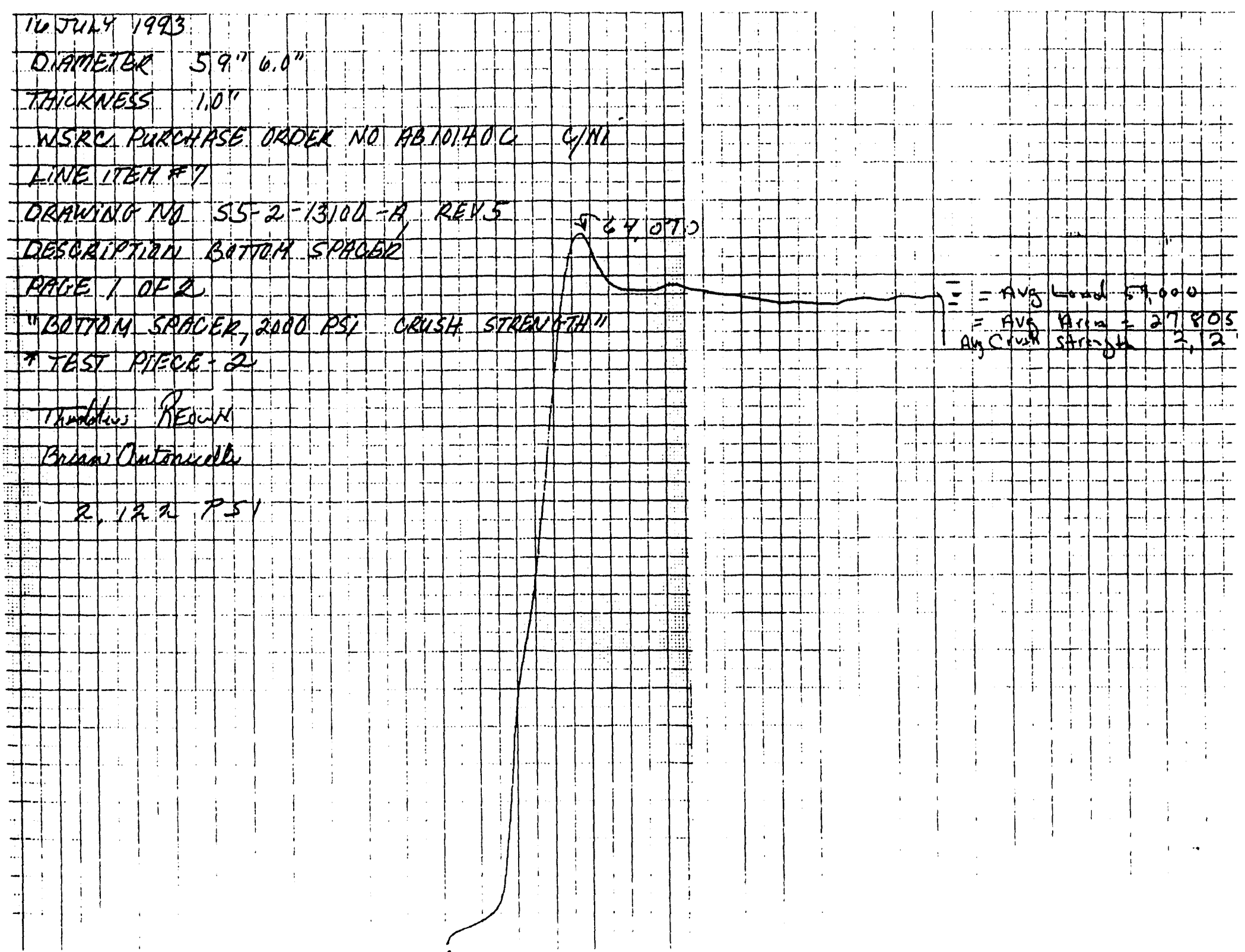


\section{APPENDIX 3 \\ Bottom Spacer \\ Drawing Number S5-2-13100 B \\ 1,000 PSI Crush Strength}

Index:

Still-Water Tool \& Manufacturing Co.

Certificate of Conformance

Coastal aluminum foil certificate of conformance

Hexcel honeycomb spacer certificate of conformance

Tube 93-1 crush strength test results (Hexcel)

Tube 93-1 crush strength test results (SRTC)

Tube 93-2 crush strength test results (Hexcel)

Tube 93-2 crush strength test results (SRTC)

Tube 93-3 crush strength test results (Hexcel) 


\section{STILL-WALTER TOOL \& MANUFACTURING CO. 375 CANNON BRIDGE RD. P.O. BOX 464 ORANGEBURG, SOUTH CAROLINA 29116-0464 \\ PHONE: 803-534-8555 FAX: 803-534-4585}

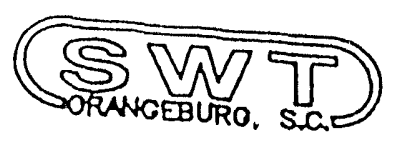

\section{CERTIECATE OF CONFORMANCE}

DATE: June 14, 1993

STILL-WALTER ORDER:___ 4057 CUSTOMER: Westinghouse SRC

PURCHASE ORDER: $A B 10140 \mathrm{C} C / \mathrm{N}_{1}$ ITEM NUMBER: 4

ORAWING NUMBER: S5-2-13100-B REV. 5 QUANTTIY:_ 10 Each

DESCRIPTION: Top Spacer MATERIAL: 5052 Aluminum

SPECIFICATION: Aluminum HEAT NUMBER: 297909

HEAT TREATING:_ Not Applicable

PROCUREMENT SPECIFICATION: None PROCUREMENT LEVEL:_ 3 STORAGE LEVELL: Not Applicable OTHER: 1000 psi Crush Strength Honeyoomb.

Still-Walter Part No: A1525A Rev. 1.

This is to certify that the item fabricated and material used on the above purchase order was manufactured to and conforms with the requirements of applicable drawings and specifications.

Still-Walter Tool \& Manufacturing Co.

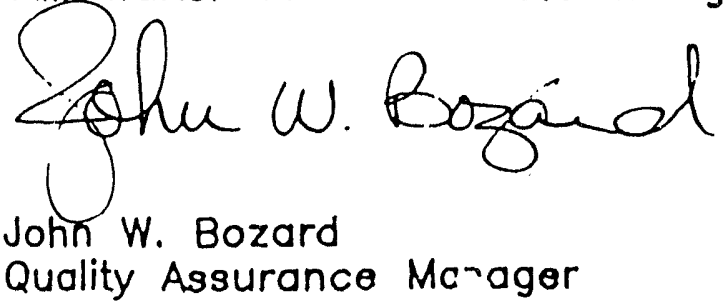


D. R. Leader

September, 1993
WSRC-TR-93-448

Page 27

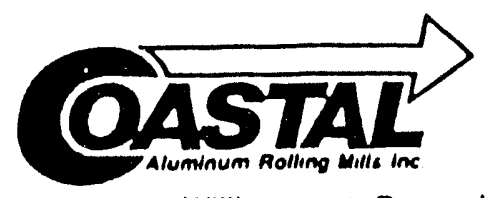

2475 Trenton Avenue - Williamsport, Pennsylvania 17701

$717.323-4430$ - FAX 717.323-6866

\section{CERTIFIED TEST REPORT}

6 - Hexcel Corp.

L $338 \mathrm{~N}$. Pennsylvania Ave.

T

T

\begin{tabular}{|c|c|c|c|}
\hline \multicolumn{2}{|c|}{$\begin{array}{l}\text { OADEA NUMAEA } \\
10110\end{array}$} & \multicolumn{2}{|c|}{$\begin{array}{l}\text { CUSTOMER PUACYUSE OAOER MUMUER } \\
31172\end{array}$} \\
\hline $\begin{array}{l}\text { AlLOY } \\
5052\end{array}$ & $\begin{array}{l}\text { TEMPEA } \\
\text { H } 191 \\
\end{array}$ & $\begin{array}{l}\text { gAvas } \\
0.0037^{\prime \prime}\end{array}$ & MOTH $23^{\prime \prime}$ \\
\hline \multicolumn{2}{|c|}{$\operatorname{mill}$} & PAAT MUMBEA & \\
\hline \multicolumn{4}{|c|}{ CHEMICAL COMPOSITION FOR ALLOY } \\
\hline \multicolumn{2}{|l|}{ ELEMENT } & n mominum & n maximun \\
\hline \multicolumn{2}{|l|}{ SILICON } & & 0.25 \\
\hline \multicolumn{2}{|l|}{ IRON } & & 0.40 \\
\hline \multicolumn{2}{|l|}{ DOPPEA } & & 0.10 \\
\hline \multicolumn{2}{|l|}{ MANGANESE } & & 0.10 \\
\hline \multicolumn{2}{|l|}{ MAGNESIUM } & 2.20 & 2.80 \\
\hline \multicolumn{2}{|l|}{ CHAOMIUM } & 0.15 & 0.35 \\
\hline \multicolumn{2}{|l|}{$\overline{Z I N C}$} & & 0.10 \\
\hline \multicolumn{2}{|l|}{ OIHEAS EACH } & & 0.05 \\
\hline \multicolumn{2}{|l|}{ OTHEAS TOTAL } & & 0.15 \\
\hline \multicolumn{2}{|c|}{ MUMINUM OAFFEAENCE } & & remainder \\
\hline
\end{tabular}

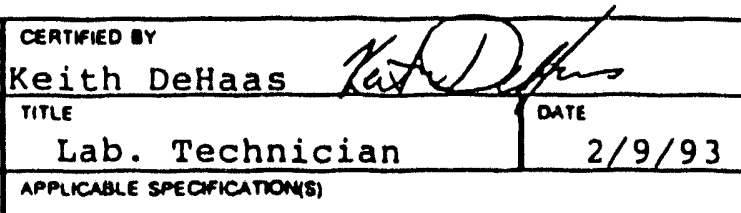

$M 11-A-81596 A$

Hexcel 1002 Rev.E

\section{CERTIFICATION}

Coastal Auminum Rolling Mills heroby cortifies that motal shipped under this order has been inspectod and lestod and found in conformance with the requirements of the epplicablie specifications es indicaled herein. Any wartanty is limited to that shown on Coastal's standard General Terms and Conditions of Sales. Test reports are on file. subject to examination.

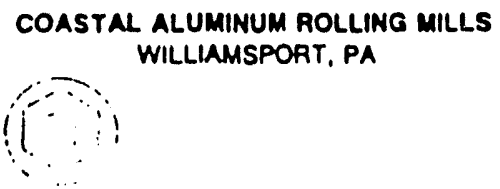

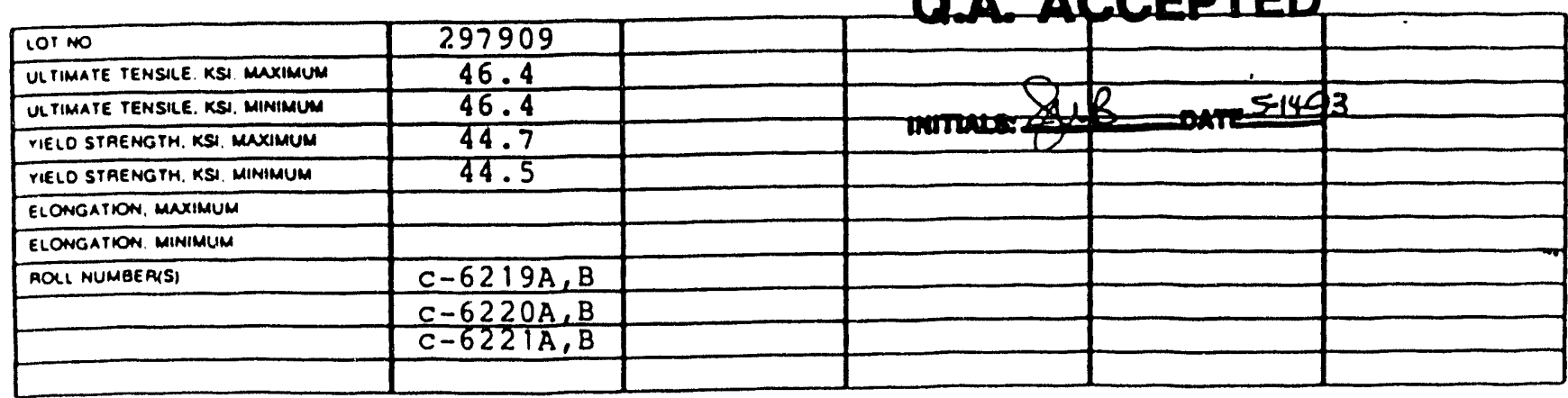

\begin{tabular}{|c|c|c|c|c|}
\hline 10110 & $\Gamma$ & & ctet & \\
\hline ULTIMATE TENSILE. KSI MUXINUM & USBC Purcha & Se Order No.HB & & \\
\hline ULTIMATE TENSILE. KSI MINIMUM & & 4 & & \\
\hline VIELO STAENCTH, KSI MAXIMUN & Line trem & & 5 & \\
\hline VIELO STAEAG IN. KSI MINIMUMM & Drawin? No. & $25-21$ & & \\
\hline ELONCA TION maximun & & To & $(1000$ pos & \\
\hline 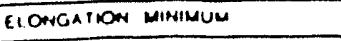 & Uescription- & & & \\
\hline ROL1 NUMBCAYSI & Page 2 & of 6 & & J \\
\hline & & & & \\
\hline
\end{tabular}


D. R. Leader

September, 1993
WSRC-TR-93-448

Page 28

PART:
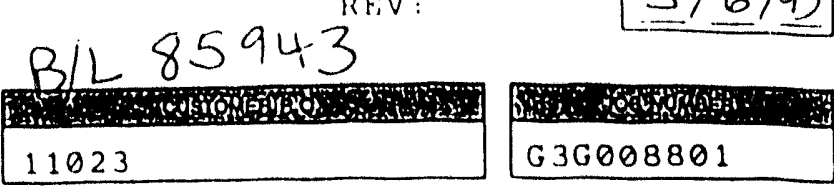

CERTIFICATION:

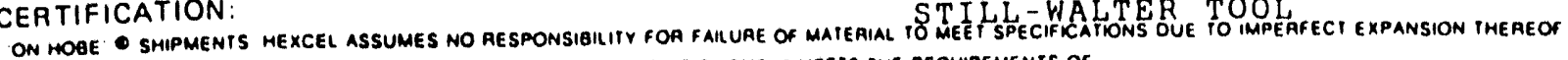
HEXCEL CEATIFIES THAT ALL HEXCEL MONEYCOMB OA HOBE in THIS SHIPMENT MEETS TME AEOUIREMENTS OF

DS -2800

HEXCEL HEREBY CERTIFIES THAT THE PARTS SUPPLIED

UNDER PO $1 / 023$ FULLY CONFORM TO THE DRAWINGS,

SPECIFICATIONS, AND PURCHASE ORDER REQUIREMENTS.

PART NO.A/52SA REV. U/A SPEC(S) DS.2800

CRUSH CHARTS IN BOX. SEE ATTACHMENT SHTS FOR SN :



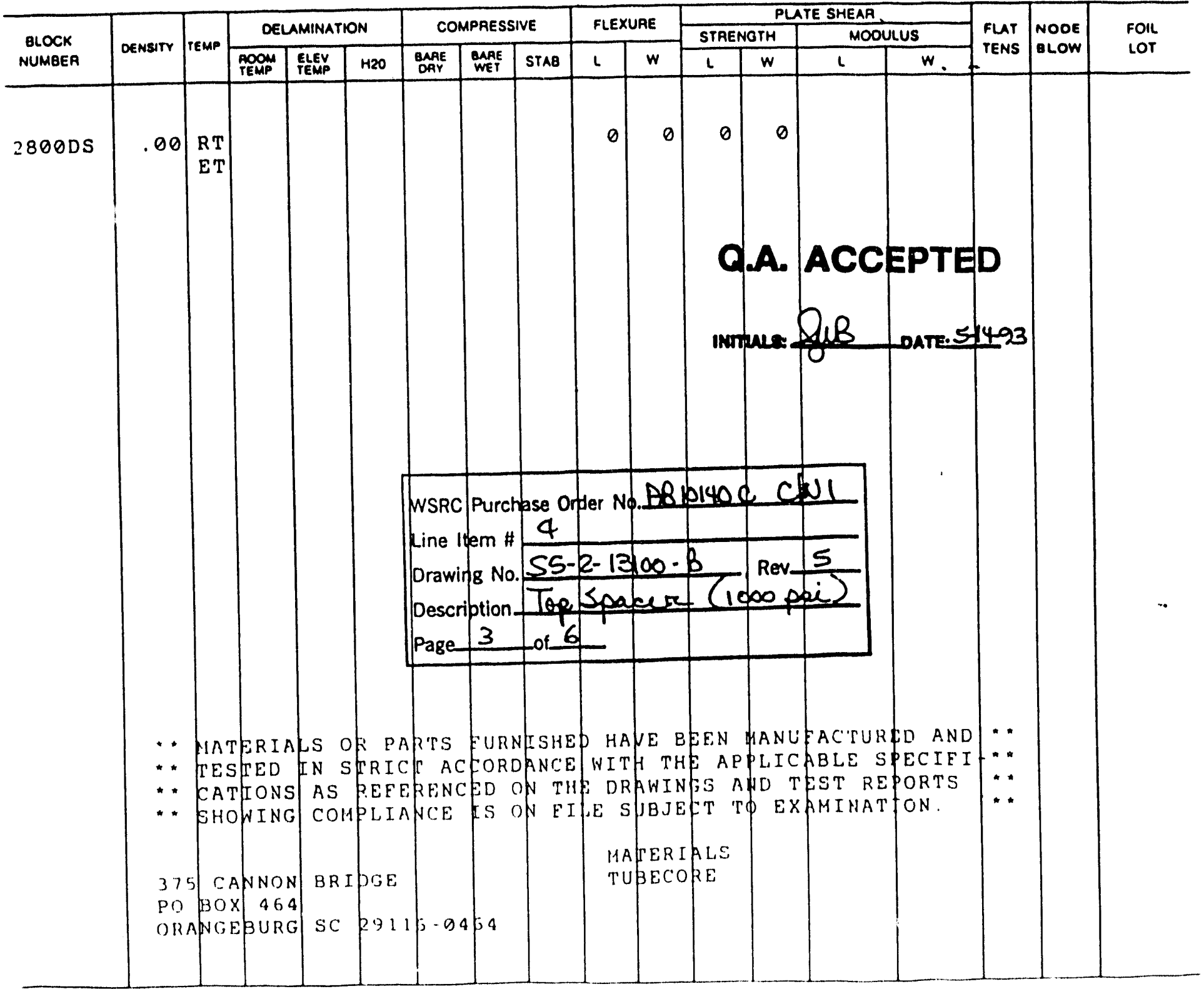


D. R. Leader

WSRC - TR - 93-448

September, 1993

Page 29

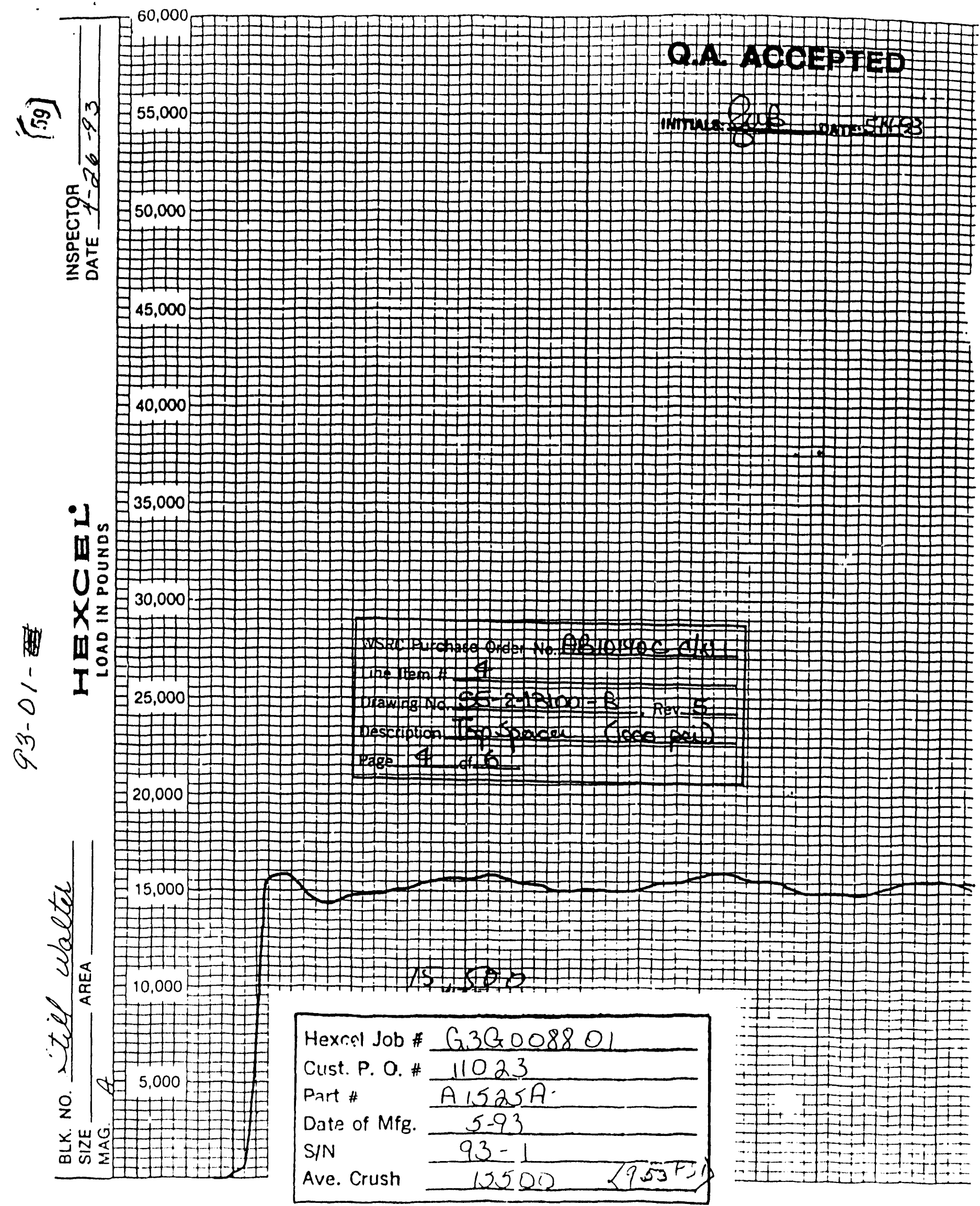




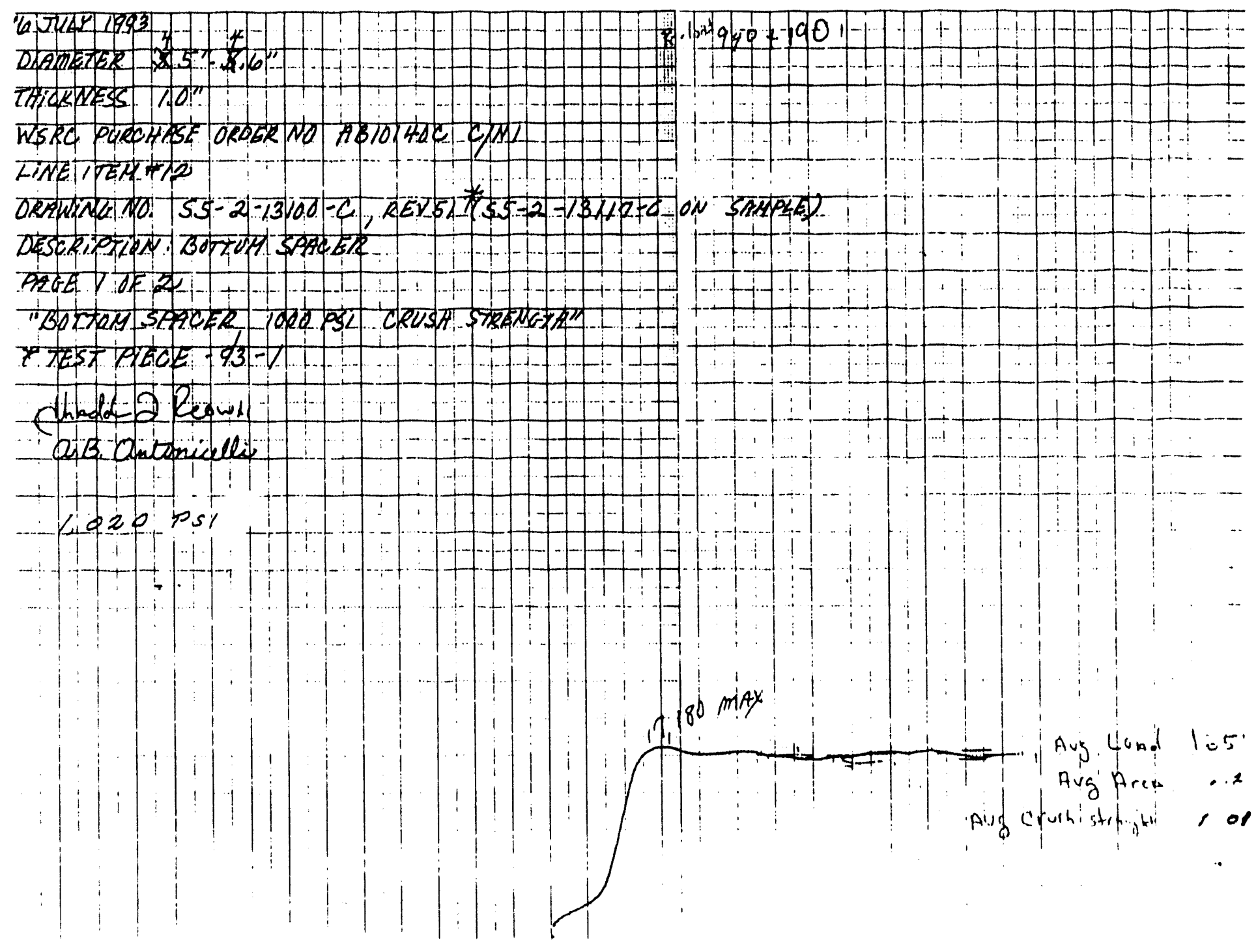


D. R. Leader

WSRC-TR - 93-448

September, 1993

Page 31

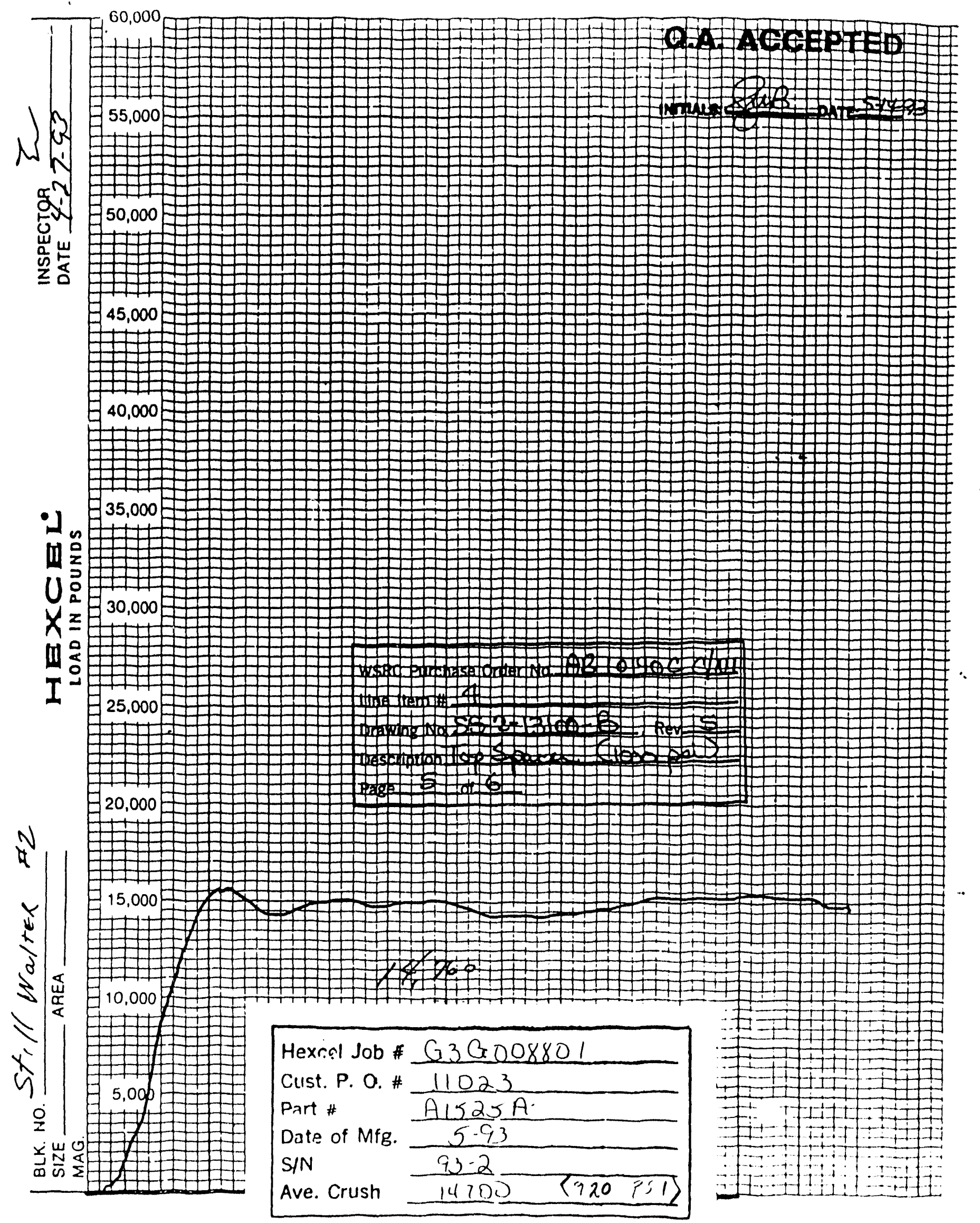




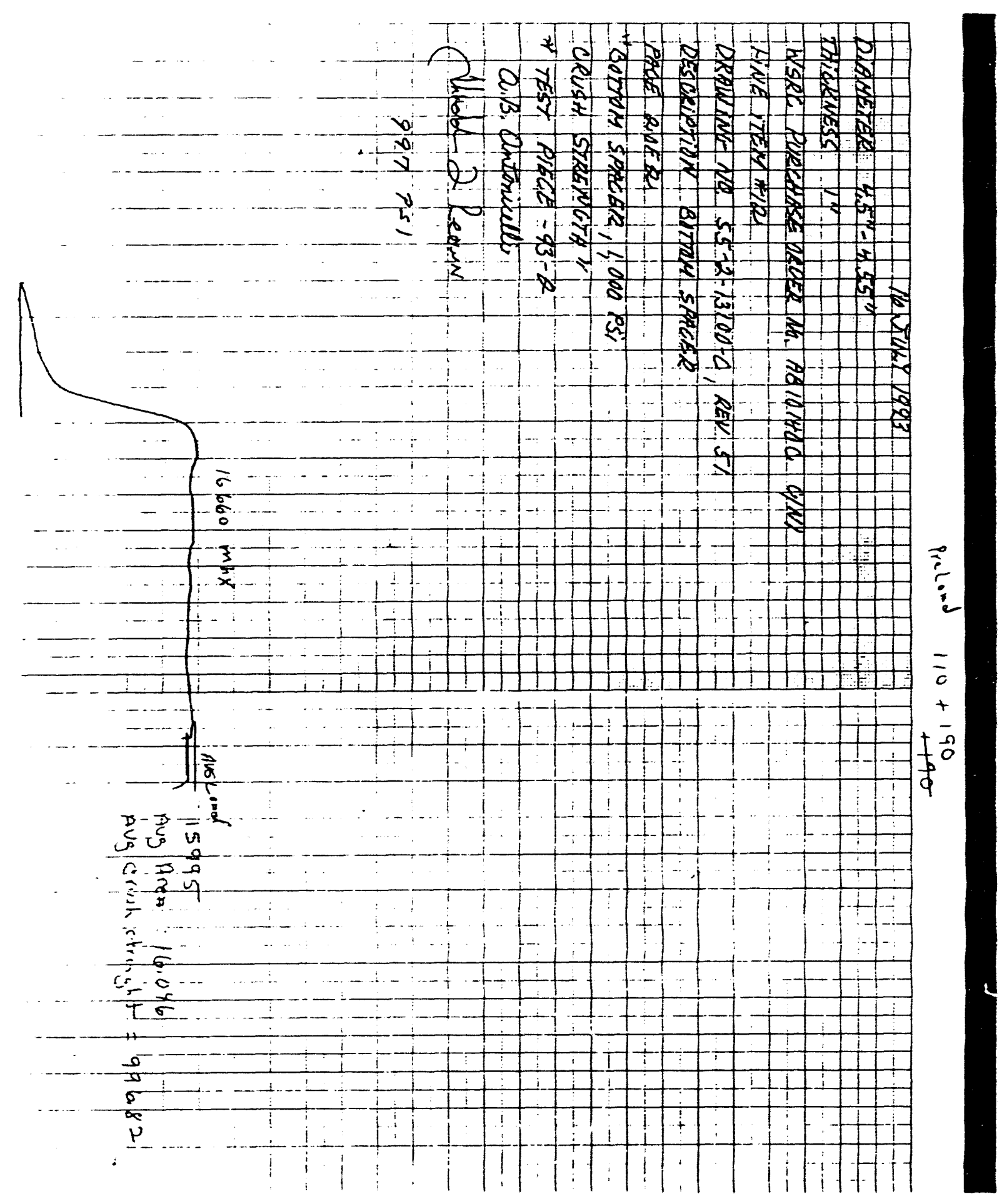

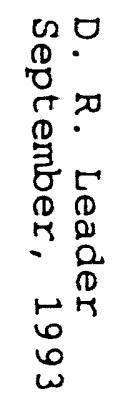

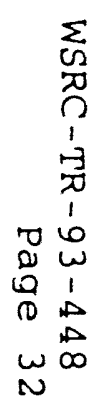


D. R. Leader

September, 1993
WSRC-TR-93-448

Page 33

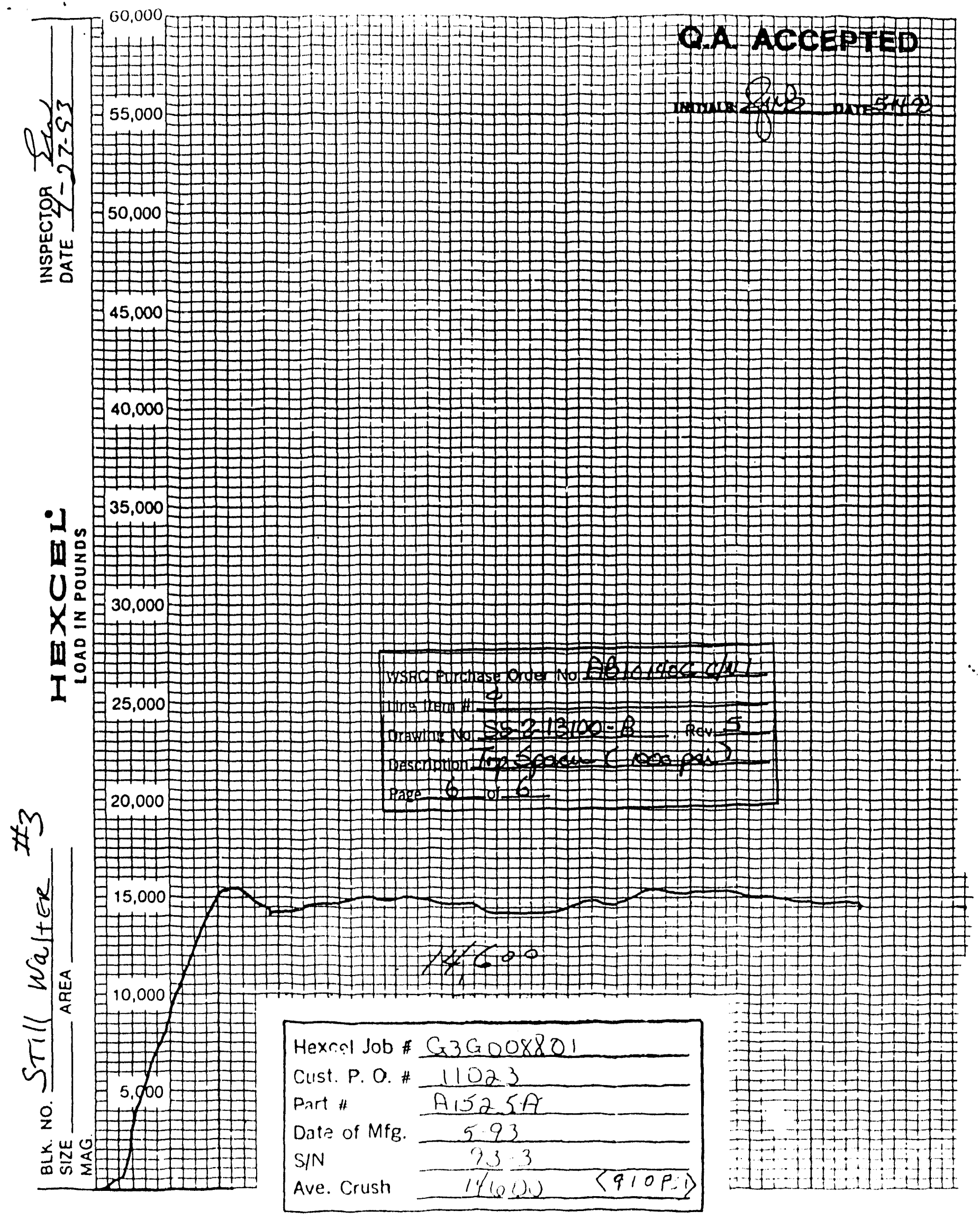




\section{APPENDIX 4 \\ Bottom Spacer \\ Drawing Number S5-2-13100 B \\ 2,000 PSI Crush Strength}

Index:

Still-Water Tool \& Manufacturing Co.

Certificate of Conformance

Coastal aluminum foil certificate of conformance 36

Hexcel honeycomb spacer certificate of conformance $\quad 37$

Tube 93-1 crush strength test results (Hexcel) 38

Tube 93-2 crush strength test results (Hexcel 39

Tube 93-3 crush strength test results (Hexcel 40 


STILL-WALTER TOOL \& MANUFACTURING CO.
375 CANNON BRIDGE RD. P.O. BOX 464
ORANGEBURG, SOUTH CAROLINA 29116-0464
PHONE: 803-534-8555

\section{CERTIEICATE OF CONFORMANCE}

DATE:_June 14, 1993

STILL-WALTER ORDER:_4____ CUSTOMER: Westinghouse SRC

PURCHASE ORDER: $A B 10140 C \mathrm{C} / \mathrm{N} 1$

ITEM NUMBER:__ 5

DRAWING NUMBER:S5-2-13100-B REV. 5

QUANTITY: 10 Each

DESCRIPTION: Top Spacer MATERLAL: 5052 Aluminum

SPECIFICATION: Aluminum HEAT NUMBER: 297909

HEAT TREATING:_ Not Applicable

PROCUREMENT SPECIFICATION: None

PROCUREMENT LEVEL: 3 STORAGE LEVEL: Net Apolicable. OTHER:_ 2000 psi Crush Strength Honeycomb. Still-Walter Part No: Al525B Rev. 1.

This is to certify that the item fabricated and material used on the above purchose order was manufactured to and conforms with the requirements of applicable drawings and specifications.

Still-Walter Tool \& Manufacturing Co.

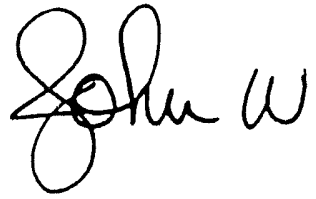

John W. Bozard

Quality Assurance Manager 
D. R. Leader

September, 1993



2475 Trenton Avenue - Williamsport, Pennsylvania 17701

717-323-4430 - FAX 717-323-686E
WSRC-TR-93-448

Page 36

\section{CERTIFIED TEST REPOAT}

8 .

L

T
Hexcel Corp.

$338 \mathrm{~N}$. Pennsylvania Ave.

Graham, TX 76046

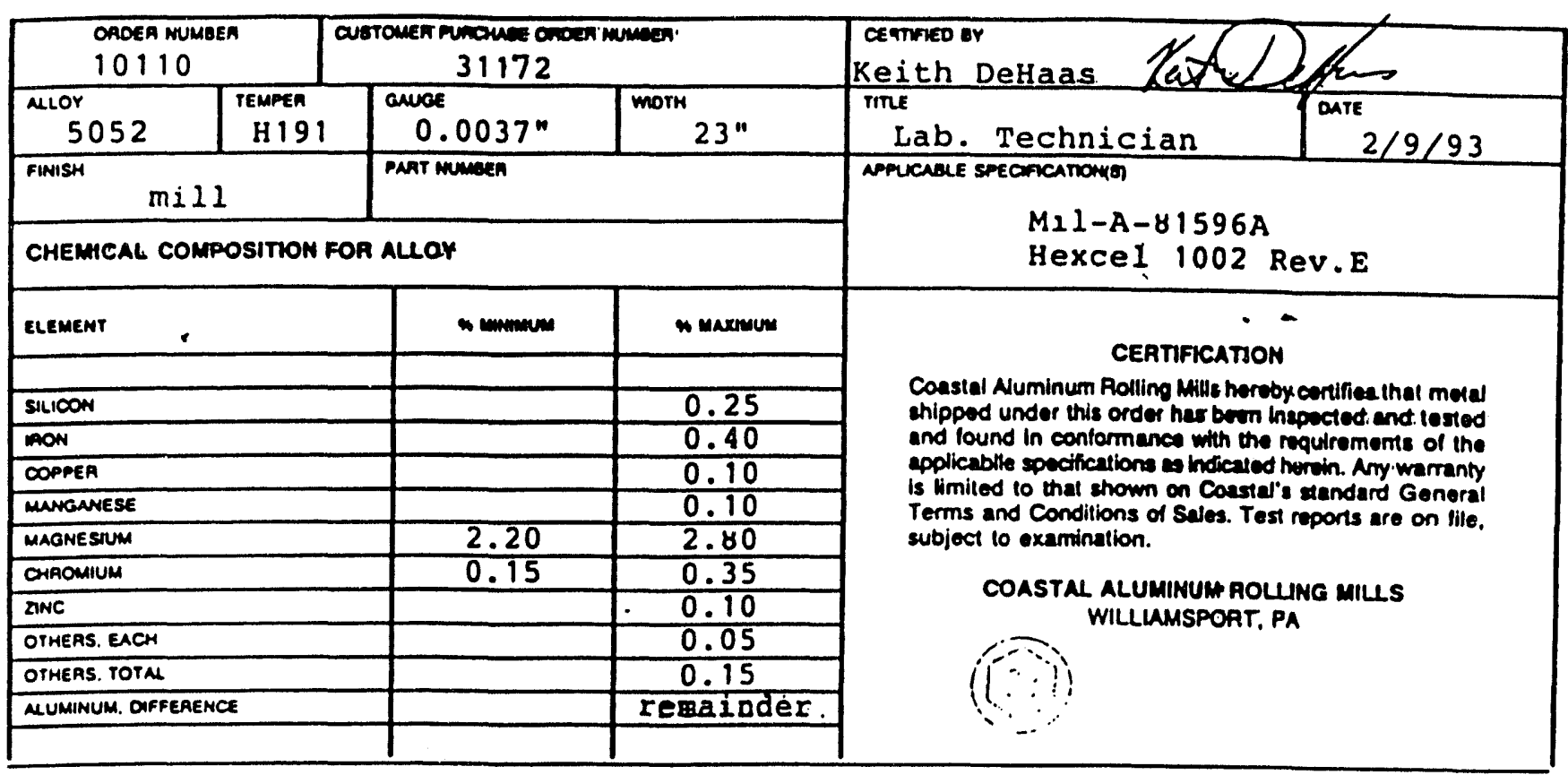

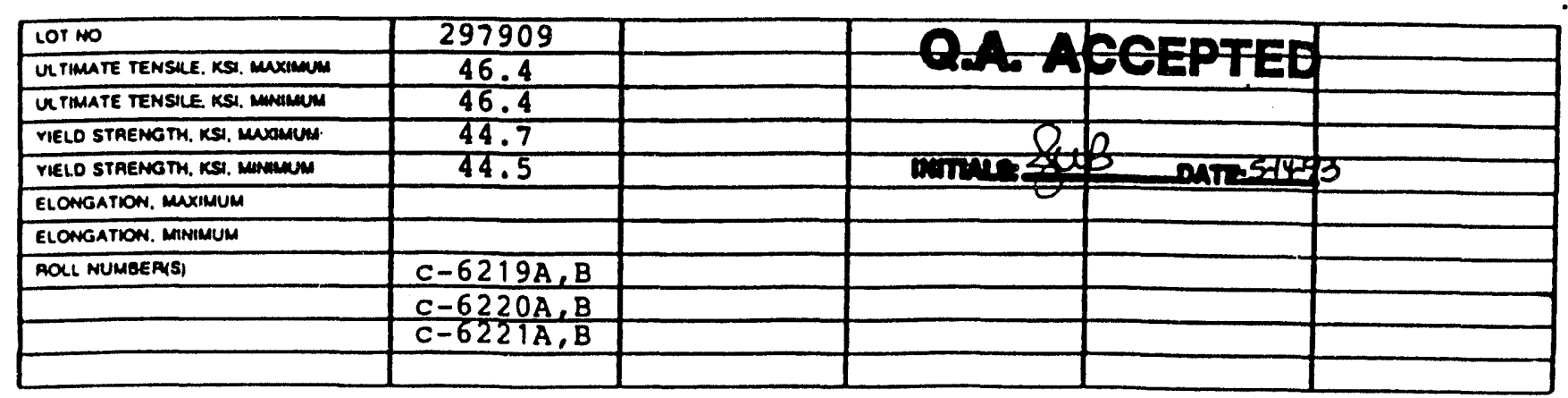

\begin{tabular}{|c|c|c|c|c|c|}
\hline LOT No & & & & & \\
\hline UTIMATE TENSUE. KSS. MUXIMUM & IISRC & urchase Order $\mathrm{No}$ & $A B \mid 040 C$ O & II & \\
\hline UTIMATE TENSLLE, KSI. INHMUM & & & & & \\
\hline VIELO STAENG TH, KSI MUXMUUM & tine $\pi$ & & & & \\
\hline VIEL STAENGTH, KSI I MUMM & Draving & No. $55-2-131$ & $D-B, \operatorname{Rev}$ & 5 & \\
\hline ELONGATOON meximus & toescrip & Fops & $(2000$ & ail & \\
\hline ELOANGation minimum & & & & & \\
\hline AOU ( NUMBE AYS) & Page & 2 of 6 & & & \\
\hline
\end{tabular}




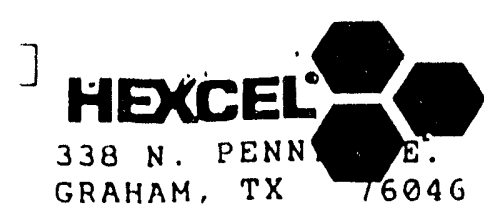

PARI':

CERTIFICATION:

STILI-WALTER TOOL

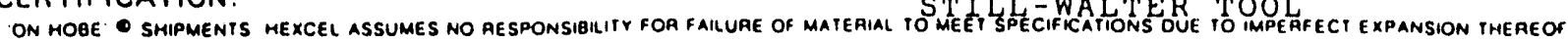

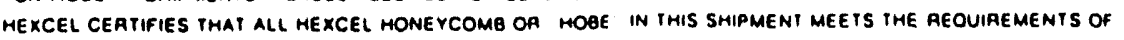

DS -2800

HEXCEL HEREBY CERTIFIES THAT THE PARTS SUPFLIED UNDER PO $/ 1023$ FULLY CONEORM TO THE DRAWINGS, SPECIFICATIONS, AND PURCHASE ORDER REQUIREMENTS.

PART NO. A $1525 B$ REV. NA SPEC(S) DS-2rOD

CRUSH CHARTS IN BOX. SEE ATTACHMENT SHTS FOR SN'S

\section{Dace Juacher}

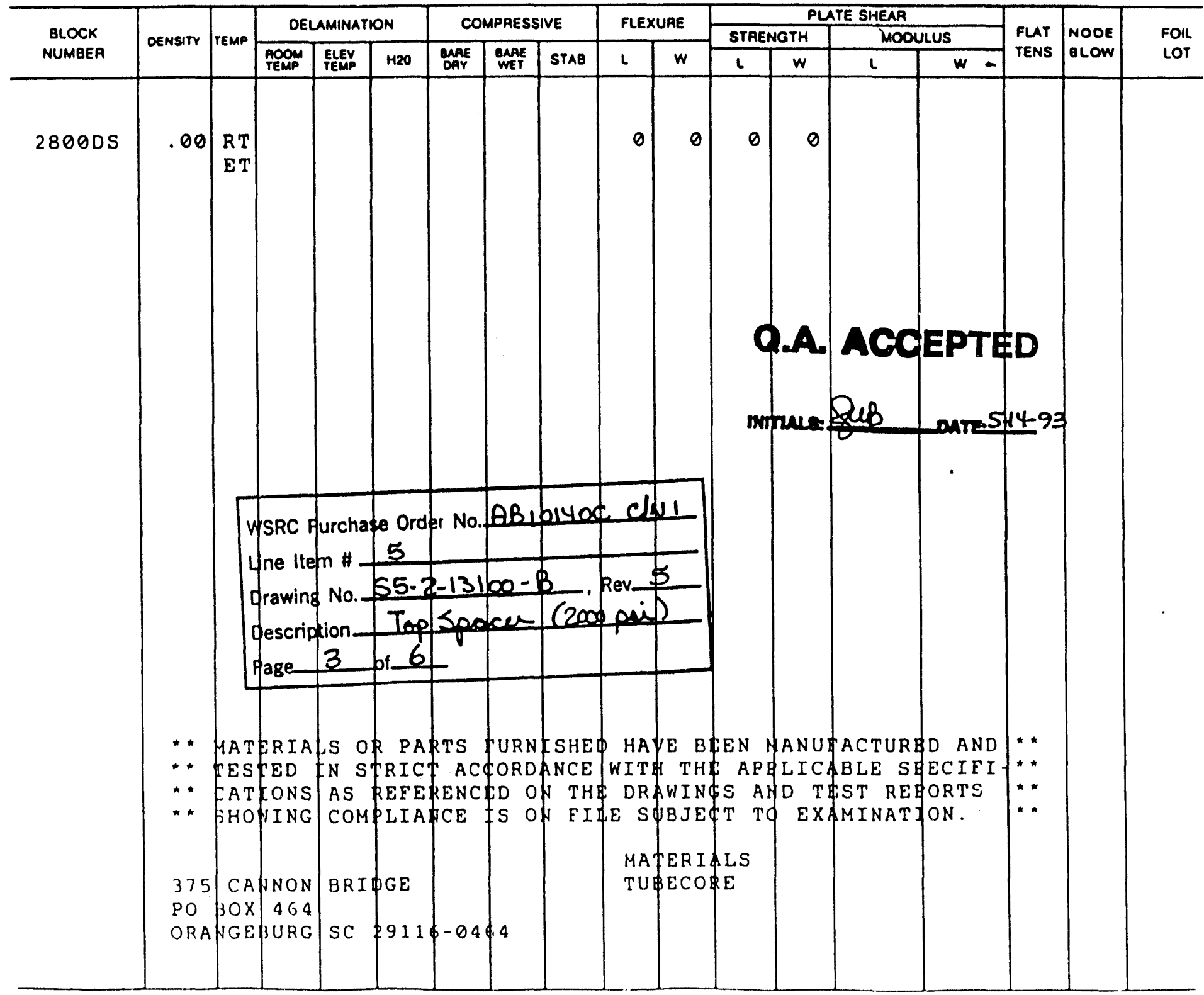







D. R. Leader

September, 1993
WSRC - TR - 93-448

page 39




D. R. Leader

September, 1993
WSRC-TR-93-448

Page 40






\section{APPENDIX 5 \\ Bottom Spacer \\ Drawing Number S5-2-13117 C \\ 1,000 PSI Crush Strength}

Index:

Still-Water Tool \& Manufacturing Co.

Certificate of Conformance

ALCOA aluminum foil certificate of conformance

Hexcel honeycomb spacer certificate of conformance

Tube 93-1 crush strength test results (Hexcel)

Tube 93-2 crush strength test results (Hexcel) 


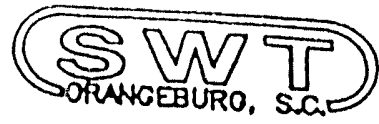 \\ STILL-WALTER TOOL \& MANUFACTURING CO. 375 CANNON BRIDGE RD. P.O. BOX 464 ORANGEBURG, SOUTH CAROLINA 29116-0464 \\ PHONE: 803-534-8555 FAX: 803-534-4585}

\section{CERTIECATE OF CONFORMANCE}

DATE:_June 14, 1993

STILL-WALTER ORDER:_4057_ CUSTOMER: Westinghouse SRC

PURCHASE ORDER: AB10140C C/N 1

ITEM NUMBER: 12

DRAWING NUMBER: S5-2-13117-C REV. 51 QUANTITY:__ 10 Each

DESCRIPTION:"13117 Spacer, 1000 psi" MATERIAL: 5052 Aluminum

SPECIFICATION: Aluminum HEAT NUMBER: 168119

HEAT TREATING: Not Applicable

PROCUREMENT SPECIFICATION: None

PROCUREMENT LEVEL: 3 STORAGE LEVEL: Not Applicable

OTHER: "13117 Spacer, 1000 psi Crush Strength"

This is to certify that the item fabricated and material used on the above purchase order was manufactured to and conforms with the requirements of applicable drawings and speclfications.

Still-Walter Tool \& Manufacturing Co.

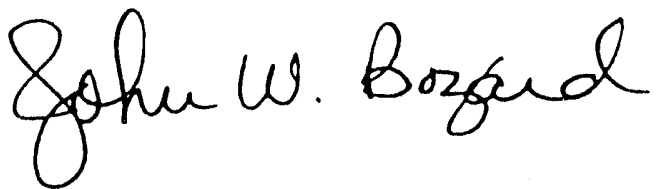

John W. Bozard Quality Assurance Manager 


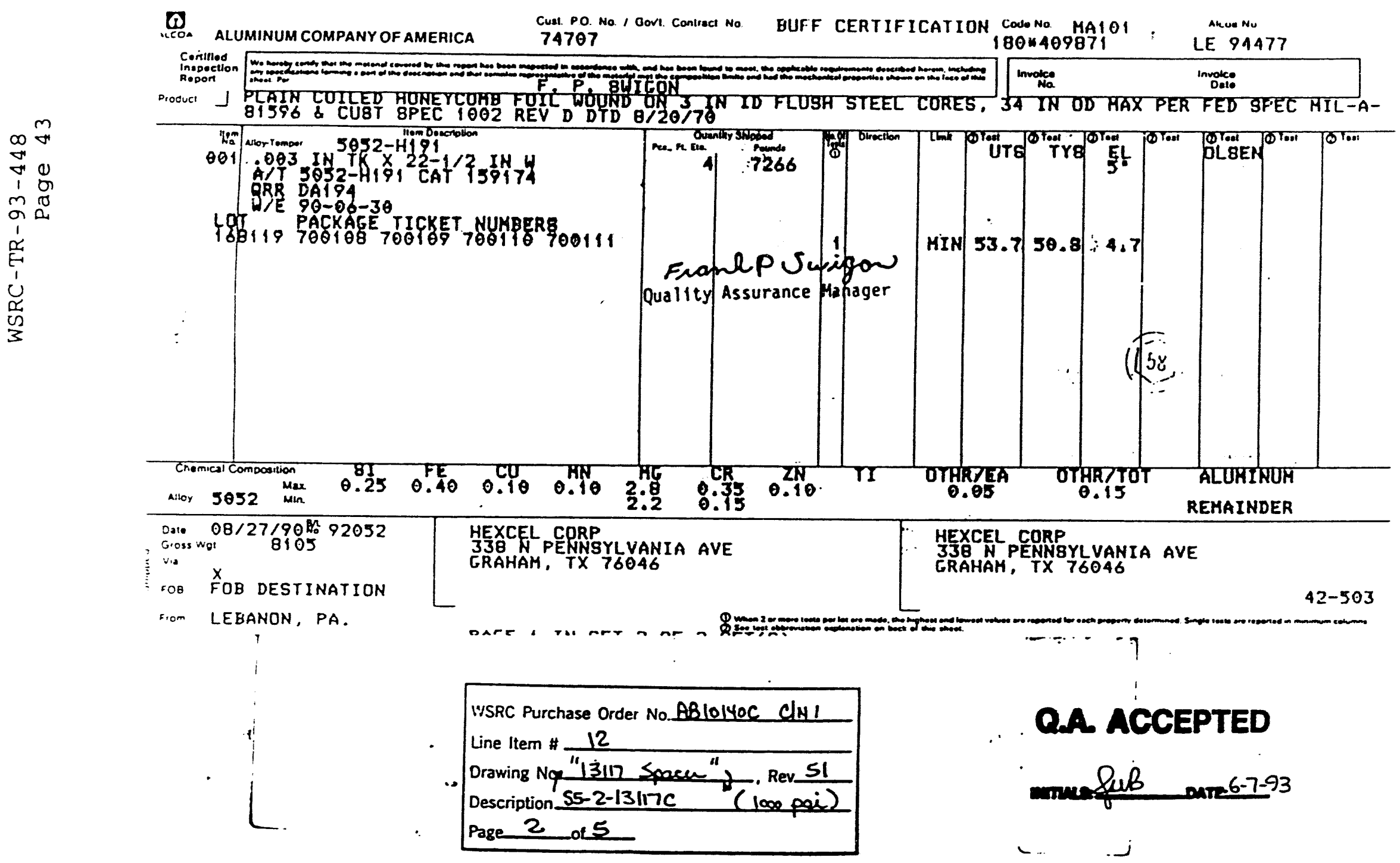




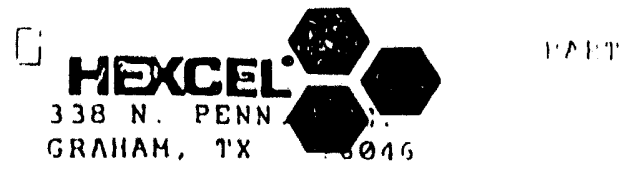

CERTIFICATION

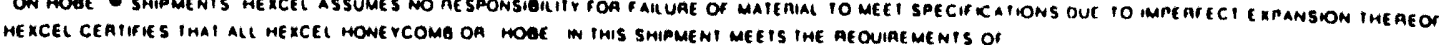
$1,5-2813$

HEXCHIL, HEREBY CLEII?IIIES THAT THE PARTS SUPHLIEL UNDER PO $1 / 025$ PULLY CONEORI: TO THE DIIAWING:, SFECIEICATIONS, ANII PURCHASE ORDRR REOUIREI!ENTS

PART NO.GTCGSAITYREV. T SPECISI DSJOUO CRUSH CHARTS IN POY. SEE ATTACHIIENT SHTS FOF : (A1527A)
Daec Z Rachenin

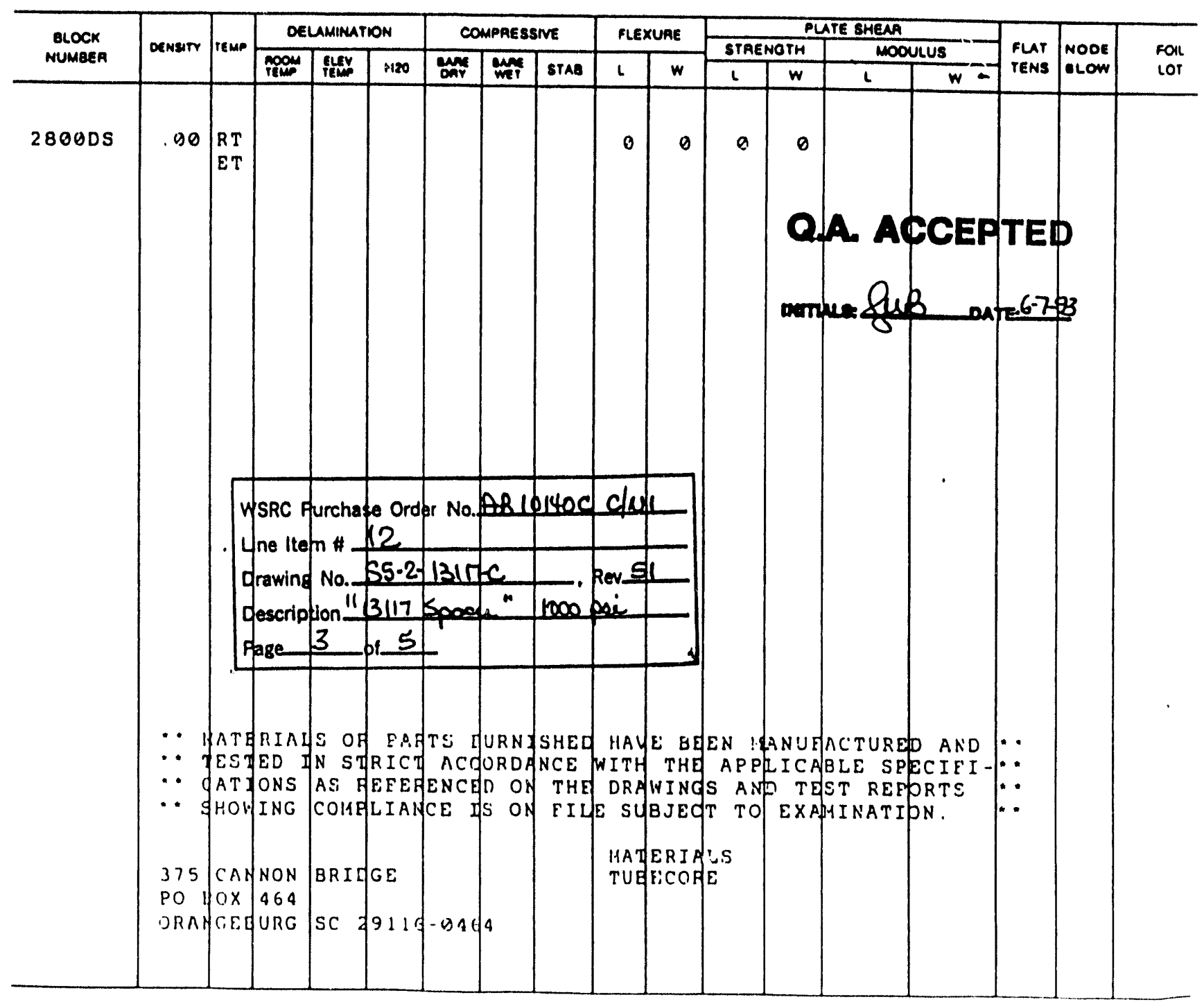




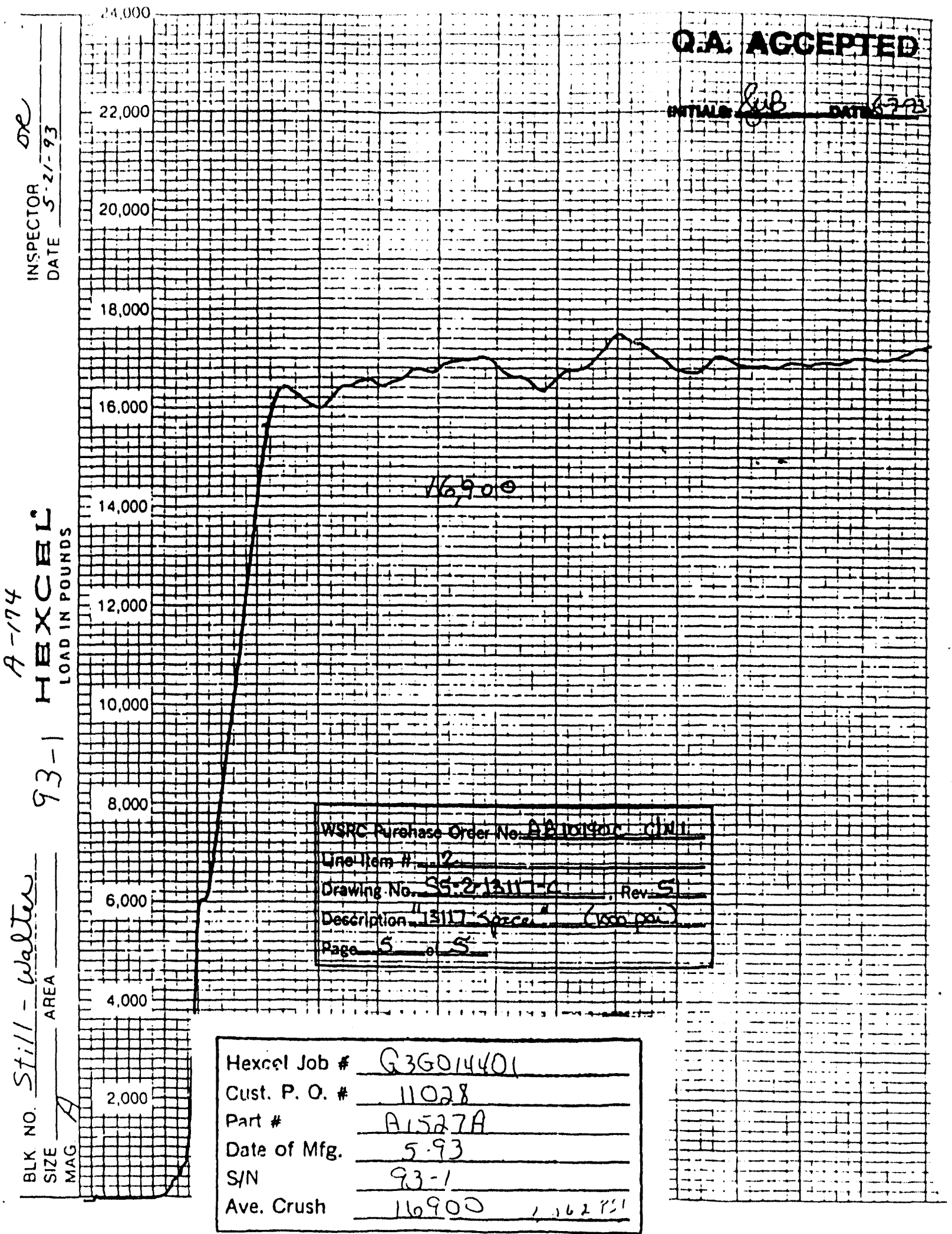




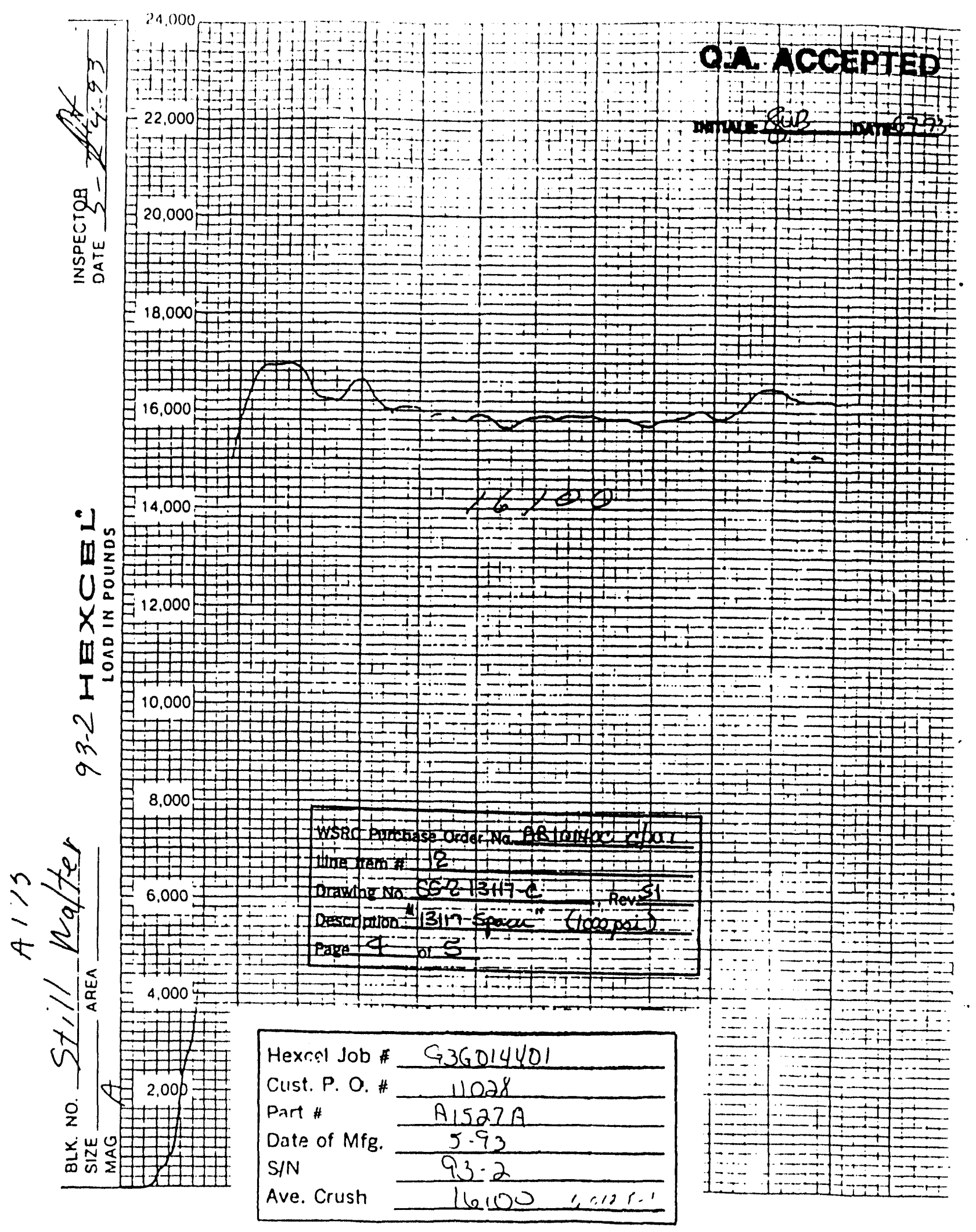




\section{APPENDIX 6 \\ Bottom Spacer \\ Drawing Number S5-2-13117 C \\ 2,000 PSI Crush Strength}

Index:

Still-Water Tool \& Manufacting Co.

Certificate of Conformance

ALCOA aluminum foil certificate of conformance 49

ALCOA aluminum foil certificate of conformance 50

Hexcel honeycomb spacer certificate of conformance 51

Tube 93-1 crush stength test results (Hexcel) 52

Tube 93-1 crush strength test results (SRTC) 53

Tube 93-2 crush stength test results (Hexcel)

Tube 93-2 crush stength test results (SRTC) 55 


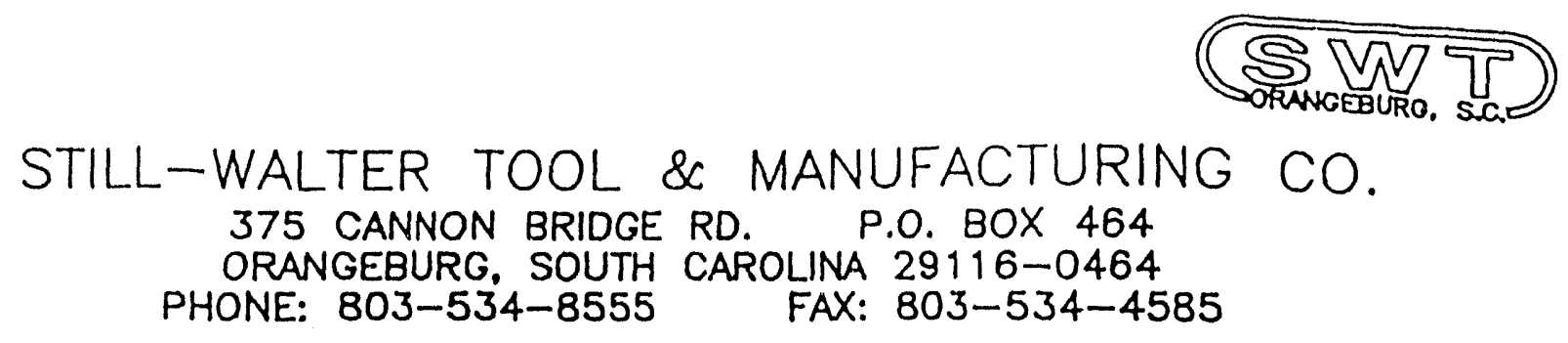

\section{CEETIETCATE OF CONFORMANCE}

DATE:_ June 14, 1993

STILL-WALTER ORDER: 4057

CUSTOMER: Westinghouse SRC

PURCHASE ORDER:AB10140C C/N 1 ITEM NUMBER: 13

DRAWING NUMBER:S5-2-13117-C REV. 51 QUANTITY: 10 Each

DESCRIPTION: "13117 Spacer, 2000 psi" MATERIAL: 5052 Aluminum

SPECIFICATION: Aluminum HEAT NUMBER: $168119 \& 102598$

HEAT TREATING:_ Not Applicable

PROCUREMENT SPECIFICATION: None

PROCUREMENT LEVEL: STORAGE LEVEL:_ Not Applicable OTHER: "13117 Spacer, 2000 psi Crush Strength"

This is to certify that the item fabricated and material used on the above purchase order was manufactured to and conforms with the requirements of applicable drawings and specifications.

Still-Walter Tool \& Manufacturing Co.

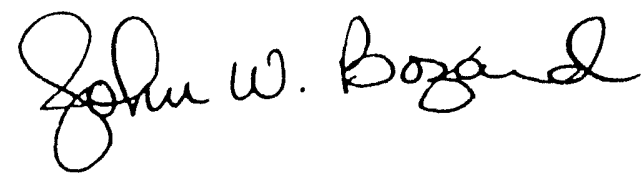
John W. Bozard Quality Assurance Manager 


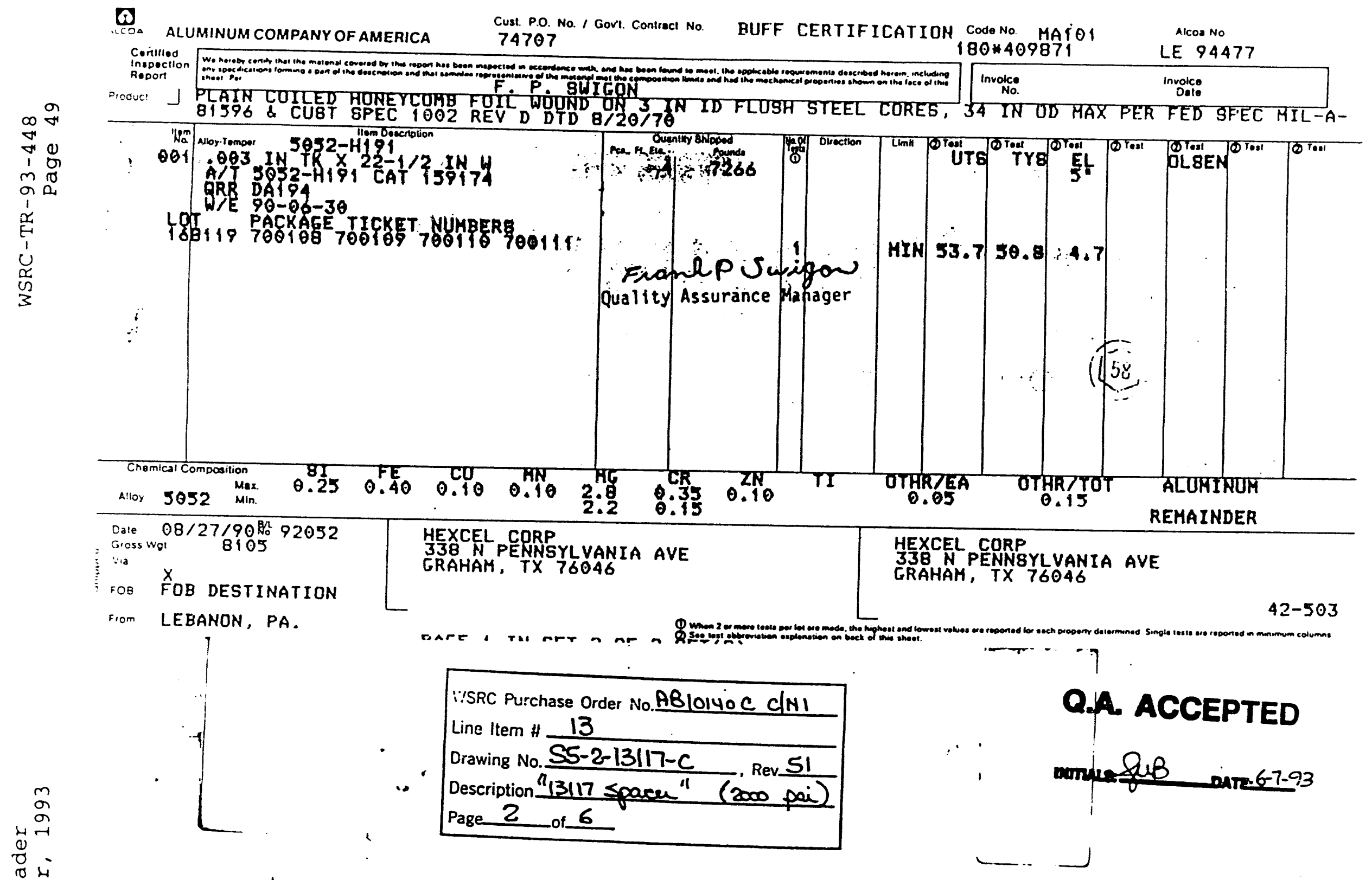







D. R. Leader

September, 1993
WSRC-TR-93-448

Page 51

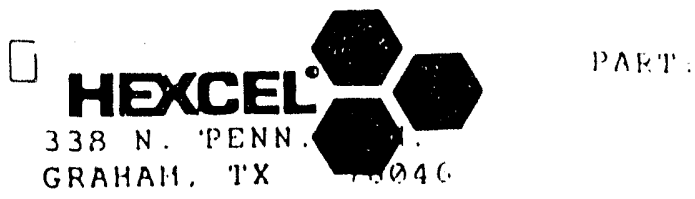

CERTIFICATION likiv:

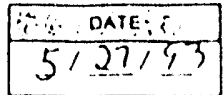

$3 / 286430$

2.

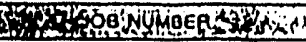
G 3Gत14402

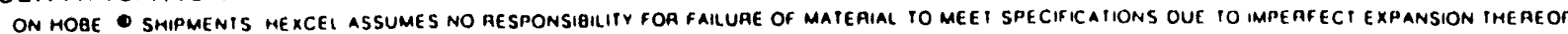

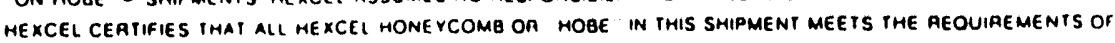

DS - 2800

HEXCEL HEREEY CERTIEJES THAT THE PARTS SUEELIE?

UNDER PO 11028 FULLY CONEORIA TO THE DRAHJHGS.

SPECIFICATIONS, AND PURCHASE ORDER REQUTREMENTS.

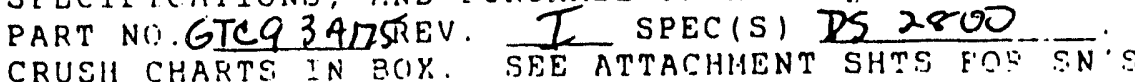

(A1527B)

Daes 7amohuser

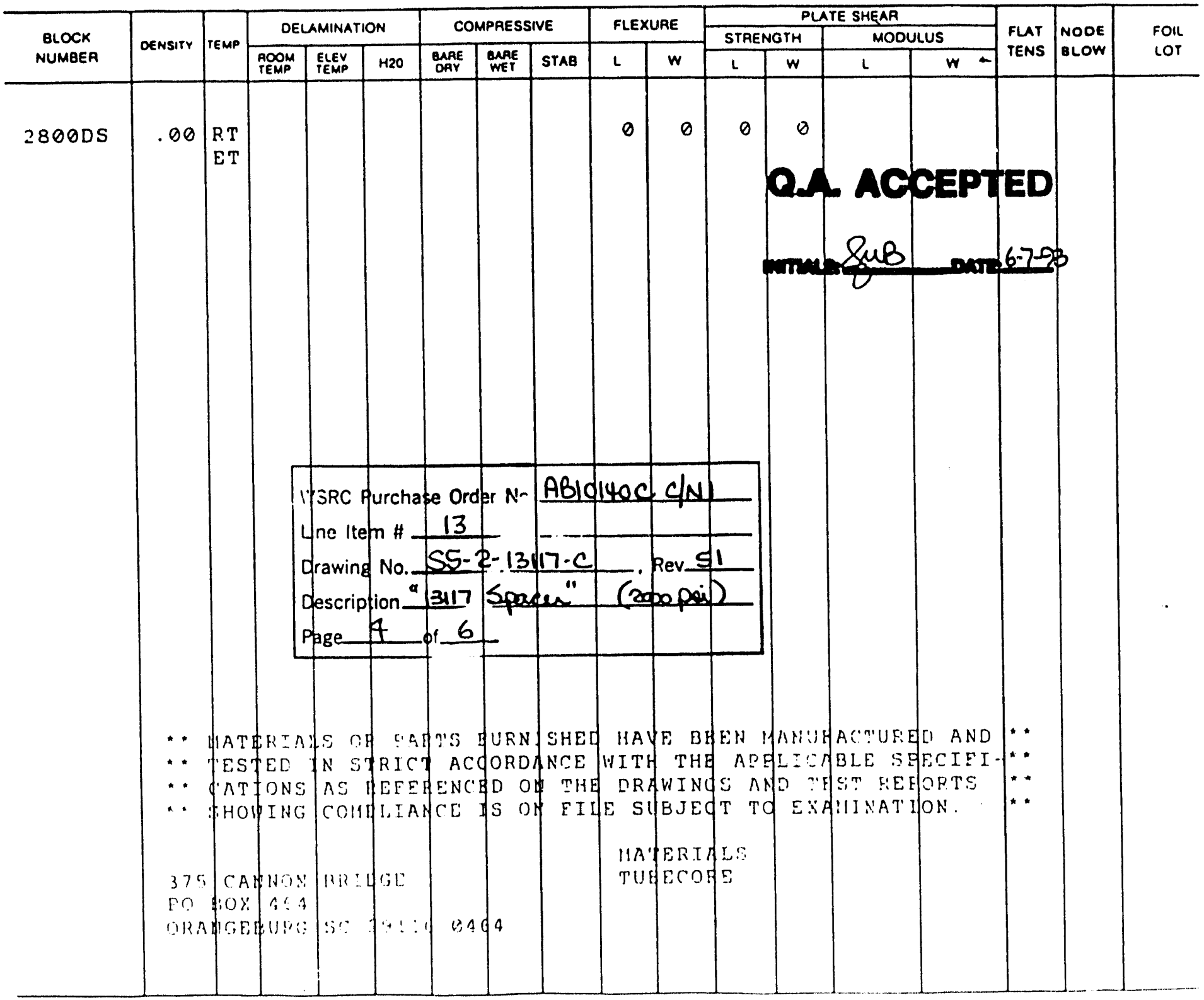







D. R. Leader

September, 1993
WSRC-TR-93-448

Page 53

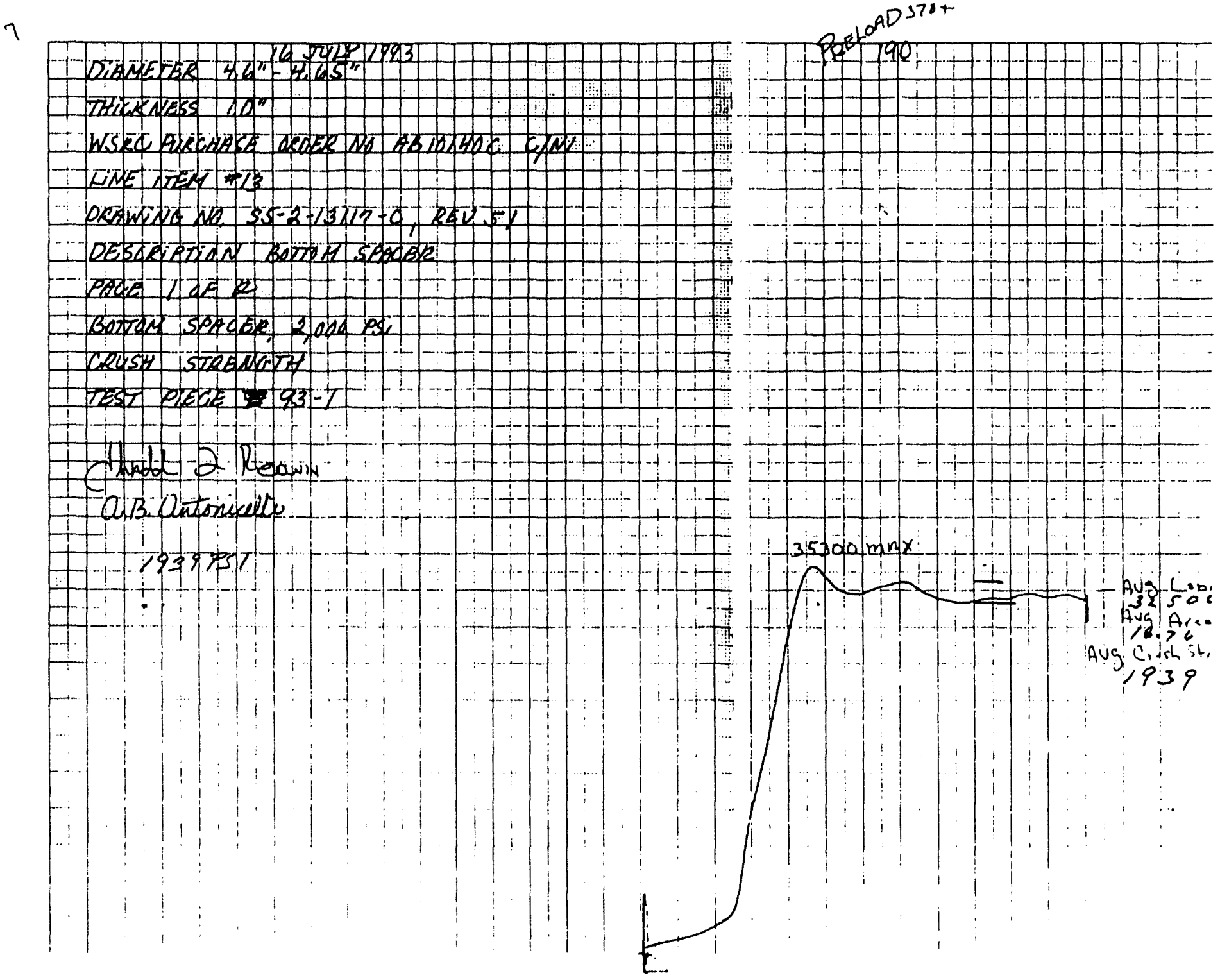




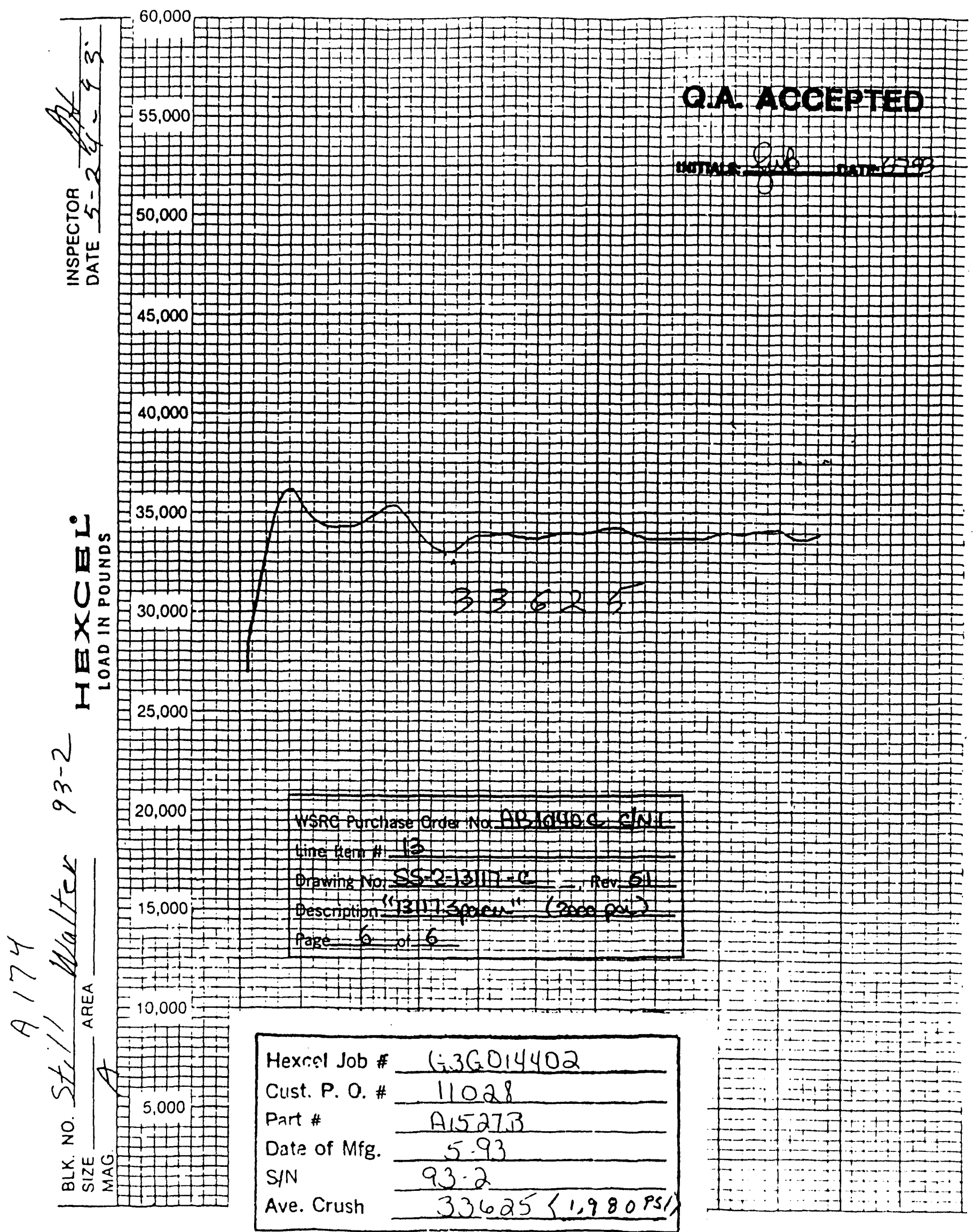


D. R. Leader

September, 1993
WSRC-TR-93-448

Page 55

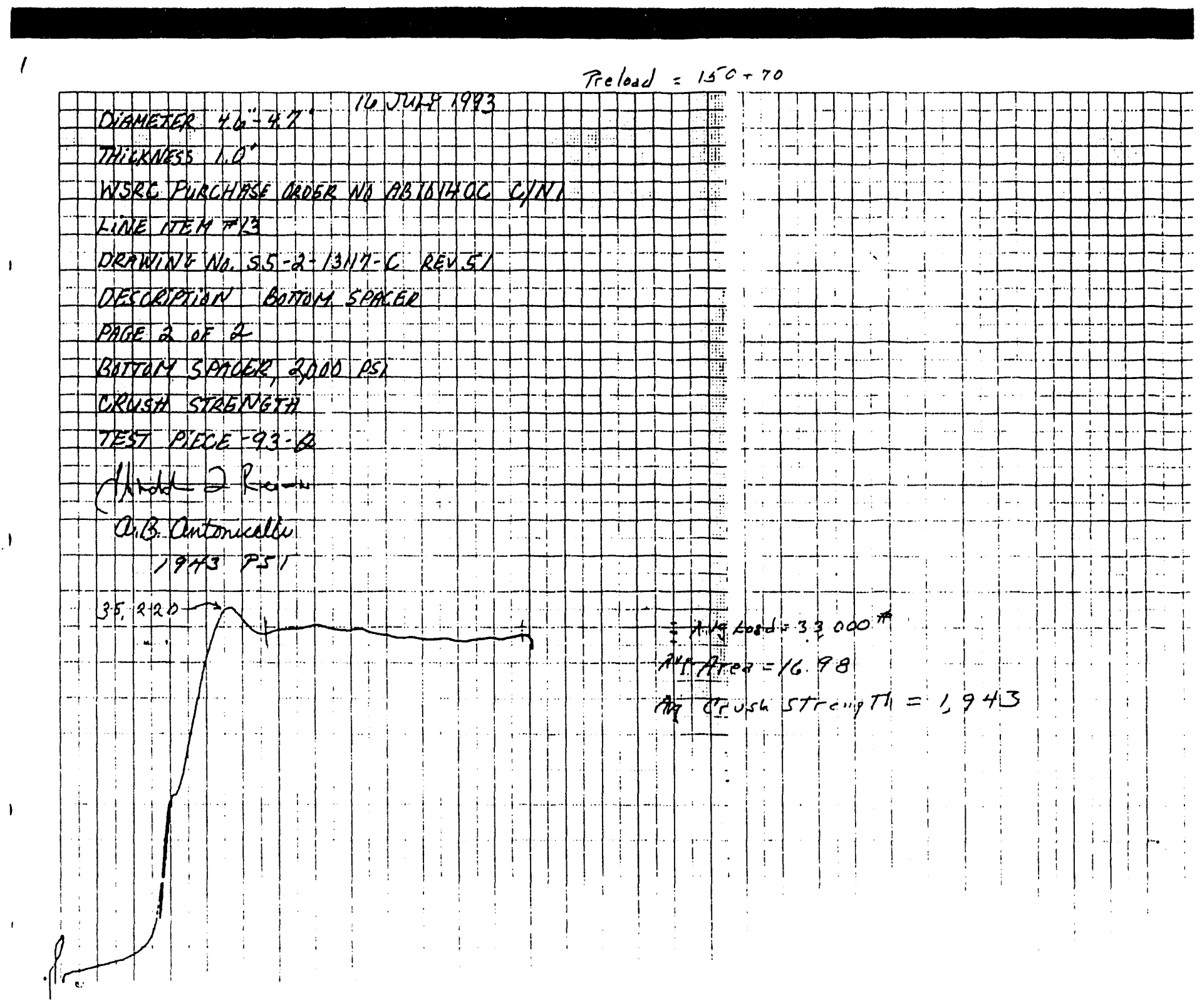


D. R. Leader

September, 1993

\section{APPENDIX 7 MATERIALS LABORATORY TEST MACHINE DATA}

Index:

Certificate of Calibration

Certificate of Calibration (continued)

58

Pen position vs. machine load 


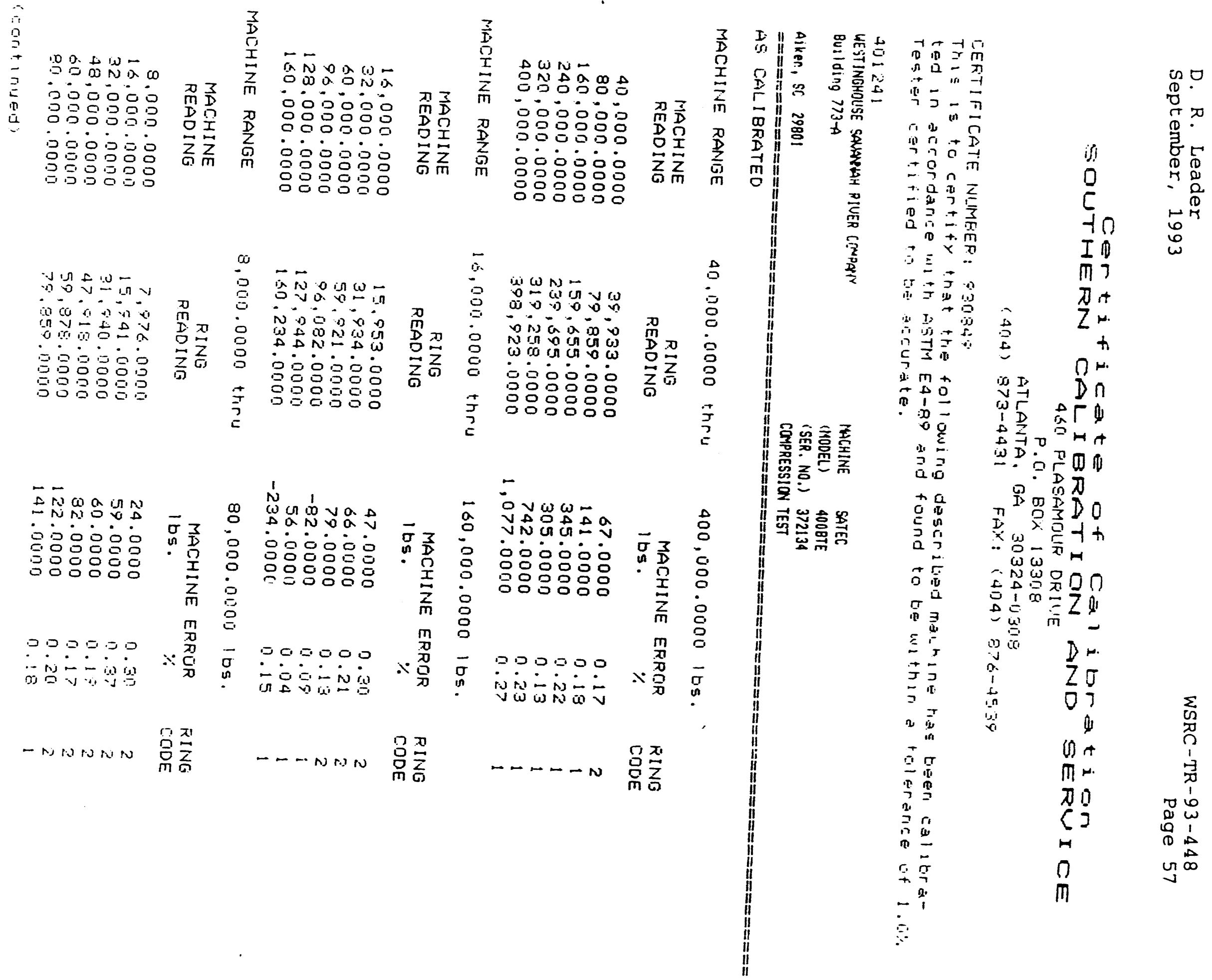




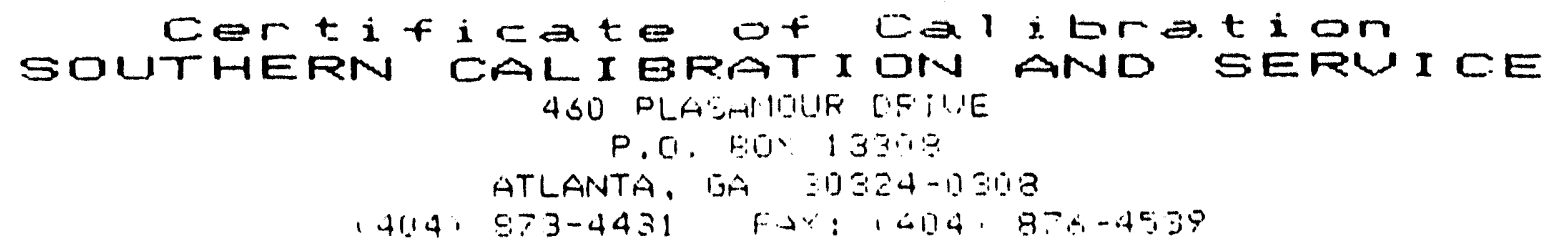

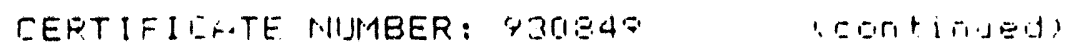

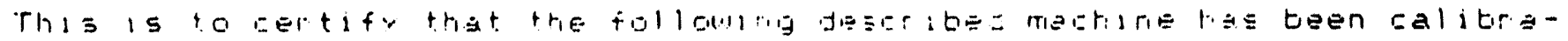

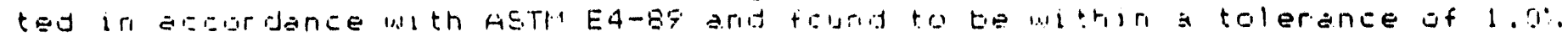

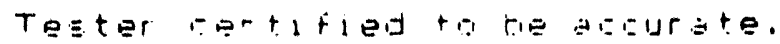

$4012+1$

WESTINGHOUSE SAMANAH RIUER COMPANY MACHINE SATEC

Building 773-A (MOOEL) QOOOBTE

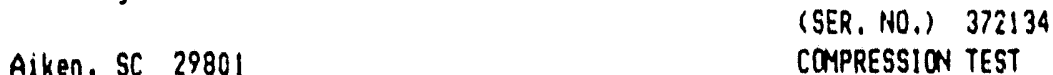

$============$
A.S DALIBRATEO

\begin{tabular}{|c|c|c|c|c|}
\hline MACHINE RANIJE & 1.600 .0000 thru & 16.0100 .90 & 01 tos. & \\
\hline $\begin{array}{l}\text { MACHINE } \\
\text { REAOING }\end{array}$ & $\begin{array}{c}\text { RING } \\
\text { REAOING }\end{array}$ & $\begin{array}{l}\text { MACHINE } \\
\text { IES. }\end{array}$ & $\begin{array}{c}\text { ERROR } \\
\because\end{array}$ & $\begin{array}{l}\text { RING } \\
\text { CDDE }\end{array}$ \\
\hline $\begin{array}{r}1,600.0000 \\
3,200.0000 \\
6,400.0000 \\
7,600.0000 \\
12,800.0000 \\
15,000.0000\end{array}$ & $\begin{array}{r}1,598.3000 \\
3,206.1000 \\
6,413.0000 \\
9,574.0000 \\
12.837 .0000 \\
16,047.0000\end{array}$ & $\begin{array}{r}1.7000 \\
-6.1000 \\
-1.3 .0000 \\
26.0000 \\
-37.0000 \\
-47.00100\end{array}$ & $\begin{array}{l}0.11 \\
0.17 \\
0.20 \\
0.27 \\
0.29 \\
0.29\end{array}$ & $\begin{array}{l}3 \\
3 \\
2 \\
2 \\
2 \\
2\end{array}$ \\
\hline
\end{tabular}

CALIBRATION APRARATUS

PR/SER."

PRSER

$15-4960$

22802

$3 \quad 3039$

\section{CAPACITY CALIBRATION LAB ANO LAB NUMBER}

600,000 lbs. MOREHOUSE 732.07/243758

60,000 lbs. NIST LAB NO. 737.229759

10,000 165. MOREHOUSE INST, 737.229759
CLASS 'A' VERIF, CAL, DATE MANUFACTURER

73300 LB. Force

3596 LB. Force

700 LB. Force
OB/O3/92 MOREHOUSE INSTRLMENT CO. 03/24/93 MOREHOUSE INSTRLMENT CO. 09/09/92 MOREHOUSE INSTRLMANT 50.

VERFICATI IN METHOO USEO: ELASTIC CALIBRATION [IE'IICE

LDAD VALLIES CORRECTED FoR TEMP OF 74 DEGREES FAHRENHEIT RING TEMP 74 DEGREES FAHRENHEIT

Enviromental coriditiori: Ambient (not applicatile)

Method of werification and pertinent data is in arcorganie lat th ASTM sperification E4-89. The testing device(s) used for this calibration have been verified per ASTM specification EP4-BS and are directiv traceable to the Natiorial Institute of Standards and Tectiriciag (NIST).

MEEts requirement: $=$ of MIL-STO-45.562A.

DATE OF CALIBRATION: 05/05/1993 BY: YICTDP. A. NAPDLILLD

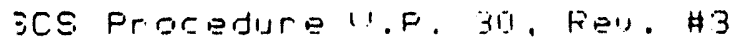

\section{SEPUIIEE FFFFE.SENTTATIUE}

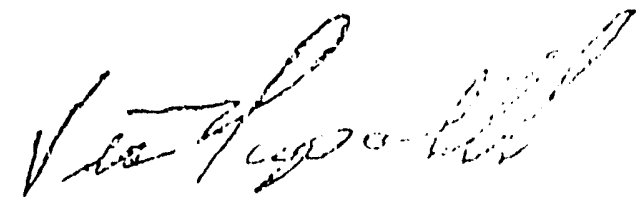


D. R. Leader

September, 1993

WSRC-TR-93-448

Page 59

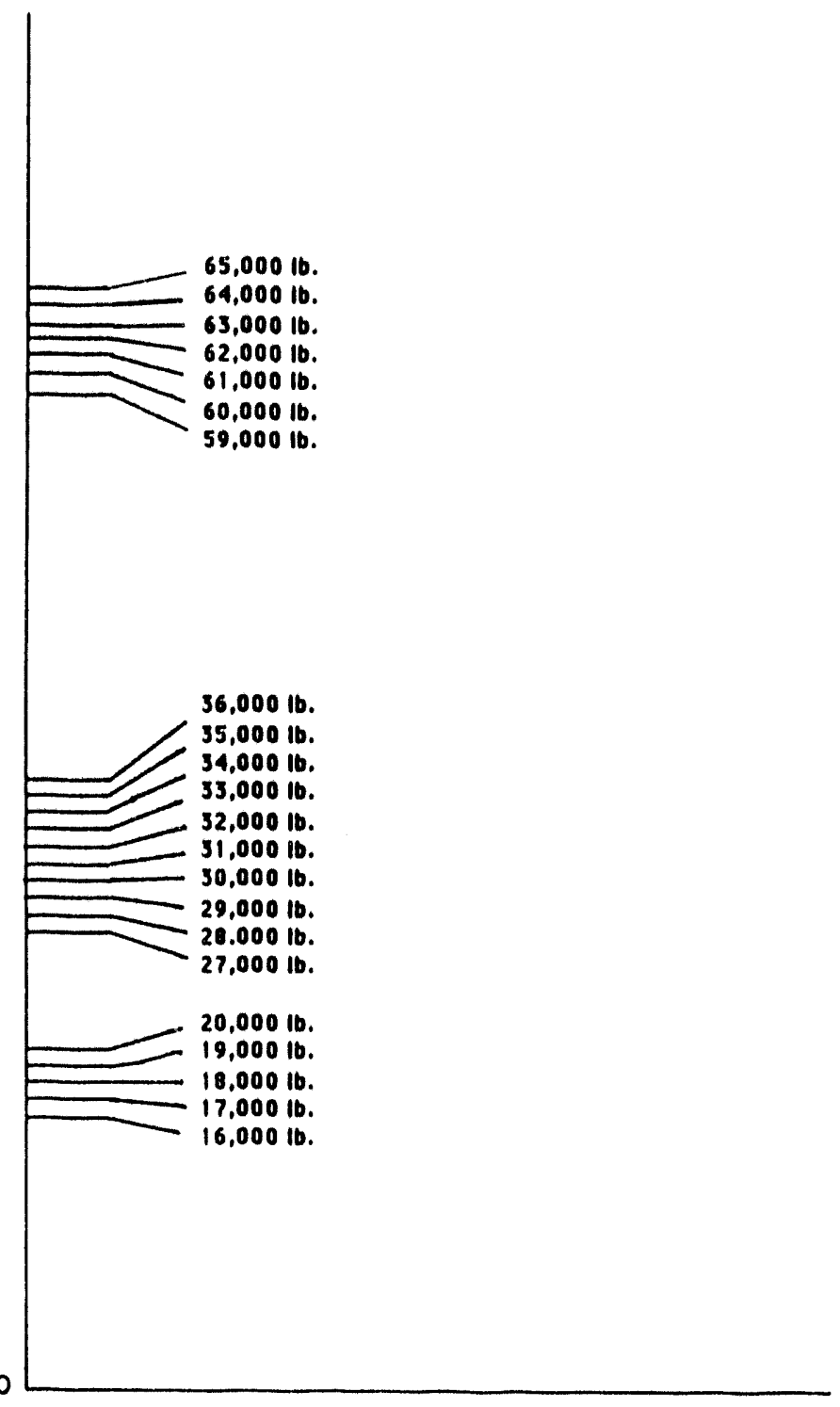

\section{Machine Load VS Vertical Pen Position for the \\ SRTC Testing Machine}


D. R. Leader

September, 1993
WSRC - TR $-93-448$

Page 60

Distribution:

J. D. Cohen,

T. L. Capaletti,

N. C. Iyer,

$773-\mathrm{A}$

773-41A

773-A

E. K. Opperman,

$305-2 \mathrm{~A}$

M. A. Whiney,

305-2A

G. Cacellie,

305-2A

R. W. Emmett,

$305-2 \mathrm{~A}$

A G. Eggers,

J. Pardo,

305-2A

SRTC Records,

MTS Files,

Job Folder 22306

992-1W

773-53A (4)

773-41A Rm. 140

730-A

Rm. 128

Project File

PTG-PF-93-001 305-2A 
